\title{
Afyonkarahisar Şuhut Ovası Yeraltısularının Hidrojeokimyasal İncelemesi
}

\author{
Simge VAROL (iD ${ }^{1 *}$, Şehnaz ŞENER ${ }^{(D)}$, Erhan ŞENER ${ }^{(D)} 2$ \\ ${ }^{1}$ Süleyman Demirel Üniversitesi, Mühendislik Fakültesi, Isparta \\ 2Süleyman Demirel Üniversitesi, Uzaktan Algılama Araştırma Uygulama Merkezi, Isparta \\ Geliş Tarihi (Received): 03.04.2021, Kabul Tarihi (Accepted): 28.05.2021 \\ $\square$ Sorumlu Yazar (Corresponding author*): simgevarol@sdu.edu.tr \\ (C) +902462111990 등 +902462111072
}

$\overline{O ̈ Z}$

Bu çalışmada, Afyonkarahisar İli Şuhut Ovasının jeolojik ve hidrojeolojik özellikleri ile yeraltısularının hidrojeokimyasal fasiyes özellikleri incelenmiştir. Çalışma alanındaki jeolojik birimler otokton ve allokton olmak üzere iki grup halinde incelenmiş ve her bir litolojik birim hidrojeolojik özellikleri ve akifer olabilme potansiyelleri bakımından gözenekli akifer, karstik akifer, yarı geçirimli ve geçirimsiz birimler olarak ayırtlanmıştır. Çalışma kapsamında, Mayıs (2019) döneminde çalışma alanındaki sondaj kuyularında 27 adet yeraltısuyu örneği alınmış ve suların fiziko-kimyasal özellikleri belirlenmiştir. Suların analiz sonuçları ve Coğrafi Bilgi Sistemlerinden (CBS) yararlanılarak iyon dağılım haritaları hazırlanmıştır. Ayrıca farklı hidrojeokimyasal değerlendirme diyagramları kullanılarak suların kimyasal süreçleri değerlendirilmiştir. Piper diyagramına göre $\mathrm{Ca}-\mathrm{Mg}-\mathrm{HCO}_{3}$ ve $\mathrm{Ca}-\mathrm{HCO}_{3}$ baskın su tipleri olarak belirlenmiştir. Gibbs diyagramlarına göre, yeraltısularının tamamı kayaç baskın bölgede bulunmakta olup belirlenen başlıca hidrojeokimyasal süreçler ise karbonat ayrışması ve silikat ayrışmasıdır. Ayrıca, iyon değişimi akifer ortamda gelişen muhtemel süreçlerden birisidir. Elde edilen sonuçlara göre, çalışma alanındaki yeraltısuyu kimyası başlıca kayaç-su etkileşiminin kontrolünde gelişmektedir. Ancak, bölgedeki tarımsal faaliyetler de su kimyası üzerinde etkindir.

Anahtar Kelimeler: CBS, hidrojeokimya, Şuhut ovası, yeraltısuyu

\section{Hydrogeochemical Investigation of Suhut Plain Groundwaters, Afyonkarahisar-Turkey}

\begin{abstract}
In this study, the geological and hydrogeological features of the Suhuhut Plain of Afyonkarahisar Province were examined and the hydrogeochemical facies features of the groundwater were investigated. The geological units in the study area were examined in two groups as autochthonous and allochthonous, and each lithological unit was distinguished as porous aquifer, karstic aquifer, semi-permeable and impermeable units in terms of their hydrogeological properties and aquifer potential. Within the scope of the study, 27 groundwater samples were taken from the boreholes in the study area in May (2019) and the physico-chemical properties of the waters were determined. Ion distribution maps were prepared by using analysis results of waters and Geographical Information Systems (GIS). Ca-Mg$\mathrm{HCO}_{3}$ and $\mathrm{Ca}-\mathrm{HCO}_{3}$ were determined as the dominant water types according to the Piper diagram. According to Gibbs diagrams, all groundwaters are located in the rock-dominated zone and determined main hydrogeochemical processes are carbonate decomposition and silicate decomposition. In addition, ion exchange is one of the possible processes that develop in the aquifer environment. According to the obtained results, the groundwater chemistry in the study area develops mainly under the control of rock-water interaction. However, agricultural activities in the region also affect water chemistry.
\end{abstract}

Keywords: GIS, hydrogeochemistry, Suhut plain, groundwater 


\section{GíRiş}

Yeraltısuyu, birçok ülkede en önemli ve başlıca tatlı su kaynaklarından biridir (Redwan ve ark., 2016). Kirleticilerin yeraltısularına etkisi daha güç olduğu için özellikle içme suyu olarak yeraltısuları tercih edilmekte olup dünyadaki içme suyunun yaklaşık yarısı yeraltı suyu akiferlerinden sağlanmaktadır (Li ve ark., 2018). Su kaynaklarının mevcut kalite durumu ve bunların kimyasal özelliklerini etkileyen çeşitli faktörler hakkında yeterli bilgiye sahip olmak, su kaynaklarını geliştirme, koruma, yönetim ve sürdürülebilir yönetimleri açısından akıllıca kararlar almak için çok önemlidir.

Yeraltısuyu yönetimi için su kimyasını kontrol eden jeokimyasal süreçler hakkında bilgi sahibi olmak gereklidir (Rao ve Chaudhary, 2019). Ancak yeraltısuyu kalitesi ve kimyası hem doğal süreçlerle (çözünme / çökeltme, iyon değişim süreçleri, oksidasyon ve indirgeme) hem de antropojenik girdilerle (tarımsal faaliyetler, kentsel ve endüstriyel atık su deşarjı, katı atıklar vb.) kontrol edilmektedir (Kazi ve ark., 2009; Şener ve ark., 2010; Varol ve Davraz, 2014). Yeraltısuyunun kimyasal özellikleri, etkileşim halinde olduğu akifer ortamın fiziksel özelliklerine, bileşimine ve etkileşim süresine göre değişmektedir. Suyun kayaç etkileşim süresi ne kadar uzun olursa, suda o kadar çok mineral çözünür (Sargın, 2010; Yetiş, 2013; Nadiri ve ark., 2013). Kayaç-su etkileşiminin yoğunluğu ve meydana gelen kimyasal reaksiyonlar, kullanım için alınan yeraltısuyunun kimyasal yapısından belirlenebilir. Bu durum bazen insan kaynaklı kirlilik dışında yeraltısularında jeojenik kirliliğe neden olmaktadır. Antropojenik kirlilikte olduğu gibi, jeojenik kirlilik sözkonusu olduğunda da yeraltısuyunun kullanımı sınırlanmaktadır. Bu nedenle yeraltısuyunun hidrojeokimyasal özelliklerinin ve kayaç-su etkileşimi sırasında meydana gelen süreçlerin bilinmesi önemlidir.
Çalışma alanı olarak seçilen Şuhut Ovası ülkemizin önemli tarım alanlarından birisidir. Bölgede, yeraltısuyu tarımsal sulamanın yanı sıra bölge halkı tarafından başlıca içme ve kullanma suyu olarak da kullanılmaktadır. Bu nedenle, farklı kullanım alanlarına sahip yeraltısularının kalitesini ve kullanımını etkileyen hidrojeokimyasal özelliklerinin belirlenmesi insan sağlığı üzerindeki etkilerinin belirlenmesi açısından da önemlidir. Bu araştırmanın amacı, Şuhut Ovası yeraltısularının hidrojeokimyasal özelliklerini ortaya koyarak su kimyasını etkileyen doğal ve antropojenik süreçleri belirlemektir. Yapılan çalışma bölgede yeraltısularının sürdürülebilir kullanımına yönelik yapılacak planlamalara katkı sağlaması açısından öneme sahiptir.

\section{MATERYAL VE YÖNTEM}

\section{İnceleme Alanının Tanıtılması}

Çalışma alanı, Afyonkarahisar'ın (GB Türkiye) 35 km güneyinde ve $42^{\circ} 49^{\prime}-4^{\circ} 80^{\prime}$ kuzey enlemleri ile $26^{\circ} 96$ '- 3014' doğu boylamları arasında yer almaktadır (Şekil 1). Ayrıca, Şuhut Ovası, İç Anadolu'da ve Akarçay Havzası içinde yer almaktadır. Havza 676,4 km²'lik bir alanı kaplamaktadır ve tarımsal faaliyetler yaklaşık 160 km²'lik bir alanda yürütülmektedir. En önemli yüzey suyu, sulama suyu olarak kullanılan Şuhut Deresi'dir (Kali Deresi). Ayrıca, sulama amacı ile inşa edilmiş ve işletmede olan Kayabelen ve Ağzıkara göletleri bulunmaktadır. Ancak bölgede tarımsal sulama için yüzey suyu yeterli değildir. Bu nedenle yeraltısuları başlıca içme suyu olarak kullanımının yanı sıra önemli miktarda sulama suyu ve kullanma suyu olarak da yoğun bir şekilde kullanılmaktadır. Tarımsal faaliyetlerin yoğun olarak yürütüldüğü ovada tarımsal kirlenme de önemli sorunlardan biridir. Kullanılan gübre ve pestisitler, sızıntı ile yeraltısularına karışarak yeraltısuyu kalitesini bozmaktadır (Şener ve Şener, 2015). 


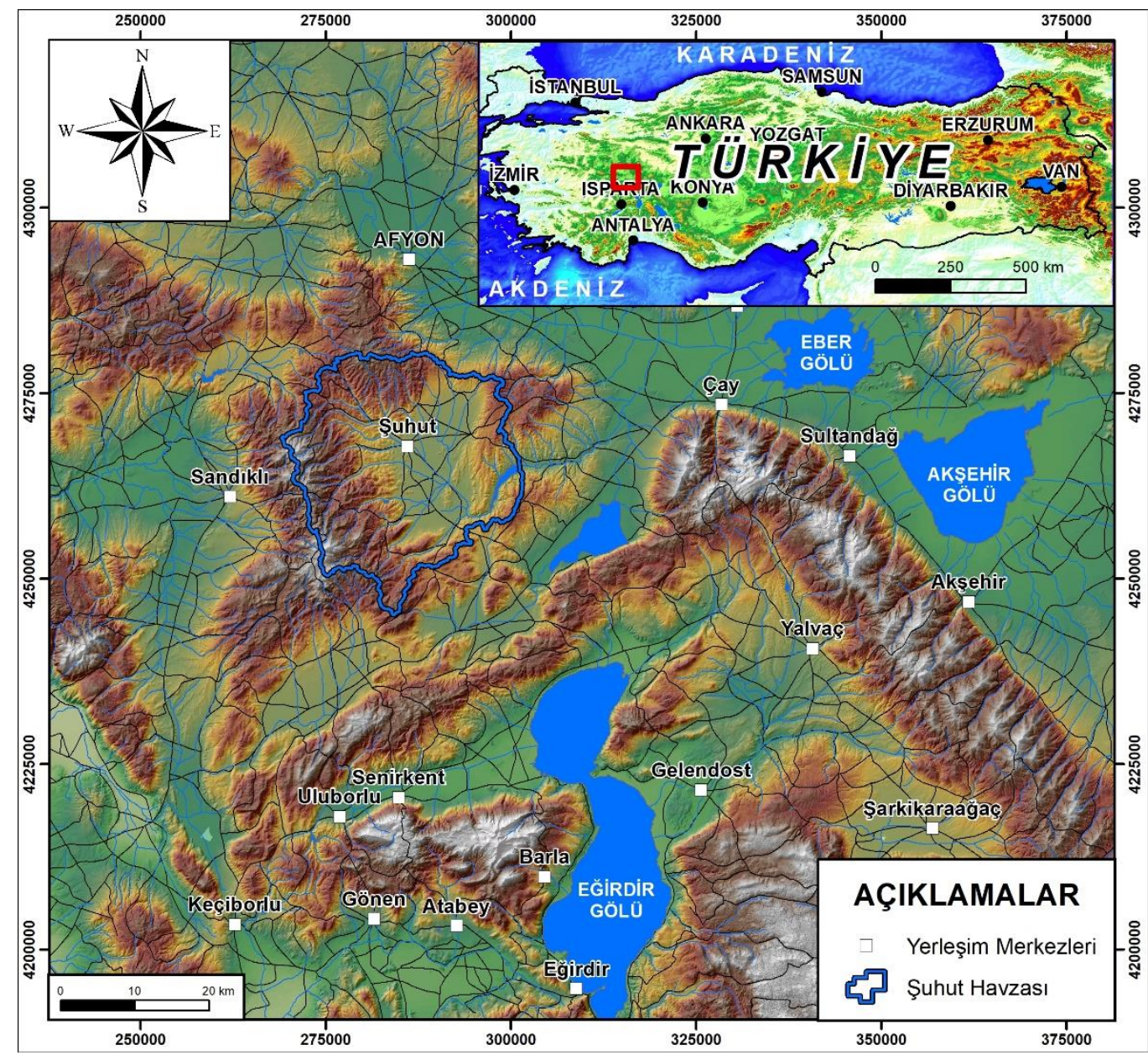

Şekil 1. Çalışma alanının yerbulduru haritası

\section{Yöntem}

Çalışma alanının jeoloji haritası, bölgede yapılmış önceki çalışmalardan ve arazi çalışmalarından faydalanılarak hazırlanmıştır. Akifer oluşturan birimlerin tanımlanmasında litolojik birimlerin hidrojeolojik özellikleri dikkate alınmıştır. Yeraltısularının hidrojeokimyasal özelliklerini belirleyebilmek için Mayıs (2019) döneminde yapılan saha çalışmaları sırasında alüvyon akiferde açılmış 27 adet sondaj kuyusundan yeraltısuyu örneği alınmıştır. Yeraltı su numuneleri, kuyulardan pompa yardımıyla 10 dakika kadar bir süre akıtılıktan ve kuyuların taze formasyon suyu ile dolması sağlandıktan sonra alınmıştır. Tüm su örneklerinin numune alma ve saklama yöntemleri ASTM (2000, 2017, 2019a, 2019b) ve TS-(1997a, 1997b) standartları göz önüne alınarak yapılmıştır. Anyon ve katyon analizleri için her numune lokasyonundan iki farklı su numunesi alınmıştır. Şişelenmiş sulardan birine katyon analizi için birkaç damla \% 0.5 nitrik asit $\left(\mathrm{HNO}_{3}\right)$ eklenmiş ve $\mathrm{pH}$ değeri düşürülmüştür. Diğer şişedeki su numunesi, anyon analizi için asitlenmemiştir.
YSI Professional Plus marka çok parametreli cihaz ile $\mathrm{pH}$, sıcaklık $\left(T ;{ }^{\circ} \mathrm{C}\right)$, elektriksel iletkenlik $(\mathrm{El} ; \mu \mathrm{S} / \mathrm{cm})$ ve toplam çözünmüş katı madde (TÇM; mg/L) parametreleri yerinde ölçülmüştür. Örnekler, katyon analizi için Bureau Veritas Mineral Laboratuvarı'na (Kanada-ISO 9002 Accredited Co.) gönderilmiş ve analizde ICP-MS cihazı kullanıımıştır. Ayrıca SDÜ (Isparta) Jeoloji Mühendisliği Bölümü Jeotermal Enerji, Yeraltısuyu ve Mineral Kaynakları Araştırma ve Uygulama laboratuvarında sülfat, klorür, karbonat ve bikarbonat analizleri titrimetrik $\left(\mathrm{CO}_{3}\right.$, $\mathrm{HCO}_{3}$ ve $\mathrm{Cl}$ için) ve baryum sülfat türbiditesi $\left(\mathrm{SO}_{4}\right.$ için) yöntemleri kullanılarak yapılmıştır. Tüm kimyasal verileri analiz etmek ve değerlendirmek için AquaChem yazılımından yararlanılmıştır. Suların kimyasal analizleri sırasında meydana gelebilecek hata payı aşağıdaki bağıntı kullanılarak anyon-katyon dengesinden hesaplanmıştır. Çalışma alanındaki yeraltısularında yapılan kimyasal analizlerde anyon-katyon dengesi ile belirlenen hata oranı \% 5'den düşük olup kabul edilebilir değerlerdedir.

$$
\mathrm{e}=[(\Sigma \text { Katyon }-\Sigma \text { Anyon }) / \Sigma \text { iyon }] \times 100(\text { mek/l) }
$$


Majör iyonların dağııım haritalarının hazırlanmasında Coğrafi Bilgi Sistemlerinden (CBS) yararlanılmıştır. Bu amaçla yeraltısuyu örneklemelerinin yapıldığı koordinatlar ile analiz sonuçları kullanılarak geodatabase yapısında bir coğrafi veritabanı oluşturulmuştur. Sözkonusu veriler ile ArcGIS 10.7 yazılımında "Ters Mesafe Ağırlıklı Interpolasyon Tekniği (Inverse Distance Weighted, IDW)" kullanılarak tematik dağılım haritaları oluşturulmuştur. Hidrojeokimyasal değerlendirmeler ise farklı diyagramlar kullanılarak yapılmıştır. Bu diyagramlardan özellikle Piper (1944) diyagramı, çalışma alanındaki yeraltısuyunun hidrojeokimyasal fasiyesini ve major iyon bolluğunu tanımlamak için kullanılmıştır. Ayrıca yeraltısuyu kimyasını kontrol eden mekanizmalar Gibbs (1970) diyagramları üzerinden yorumlanmıştır.

\section{BULGULAR VE TARTIŞMA}

\section{Jeoloji ve Hidrojeoloji}

Çalışma alanında Paleozoik'ten Kuvaterner dönemine kadar oluşan farklı kaya grupları gözlenmektedir. Bunlar otokton ve allokton gruplar olup çalışma alanının jeoloji haritası Şekil 2'de verilmiştir. Çalışma alanında gözlenen allokton birimler Sütlaçtepe, Ortatepe, Koyuntepe, Afyonluk ve Bakırdağ formasyonlarıdır. Bu birimler çok dar alanlarda ve çalışma alanının güneyinde haritalanmıştır. Çoğunlukla kumtaşı, kireçtaşı, çörtlü kireçtaşı ve radyolarit birimlerinden oluşan bu birimler bölgede uyumsuz olarak yer almaktadır. Diğer allokton birim ise peridodit, serpantinit, harzburjitten oluşan ofiyolitik karmaşıktır (Özgül, 2000).

Bölgedeki temel kayaçları oluşturan en eski otokton birimler Yalnızağaç Formasyonu, Afyon metamorfikleri ve Karahasan formasyonlarıdır. Bu birimler Paleozoik yaşIıdır. Karahasan Formasyonu kireçtaşlarından oluşmakta; Yalnızağaç Formasyonu ve Afyon Metamorfikleri ise çoğunlukla mermer, kalk şist, albit-klorit-muskovitkuvars şist ve metakonglomera gibi metamorfik kayaç grupları içermektedir. Ovanın güneyinde geniş bir alanı kaplayan Mesozoyik birimler İlyaslı, Kocadere ve Karaçal formasyonlarıdır (Özgül, 2000). Çoğunlukla rekristalize kireçtaşı biriminden ve üst seviyelerine doğru kırmızı renkli konglomera, sarı renkli kumtaşı, marn, daha üst seviyelerde şeyl ve yastık lavlardan oluşmakta olan bu birimler Üst Triyas-Jura yaşlıdır. Senozoik yaşlı birimler çalışma alanında oldukça geniş bir alanda gözlenmektedir. Bunlar kiltaşı ve kireçtaşlarında oluşan Karataş Formasyonu ile Kumalar Formasyonudur (Özgül, 2000).

Kumalar Formasyonu, masif tüf, tüf, aglomera, marn, kumtaşı ve andezit, bazalt, trakitten oluşan volkanik üyeler içermektedir. Ayrıca Kumalar Formasyonunun iki farklı üye birimi haritalanmıştır. Bunlar volkanik ve kireçtaşı üyeleridir. Volkanik kayaçlar, Neojende meydana gelen ve tüm sistem boyunca devam eden büyük bir volkanik aktivitenin ürünü olarak dasitik tüfler, aglomera, trakitler ve trakit tüfleri şeklinde bölgede oldukça geniş alanları kaplamaktadır. Tüm birimleri uyumsuz bir şekilde örten alüvyon, nehir yataklarında, havzalarda ve ovalarda biriken kum, çakıl ve kil gibi mevcut tutturulmamış güncel çökellerdir. Çoğunlukla çakıllı kum seviyeleri ile temsil edilen alüvyon, yer yer ince kil şeritleri içermektedir (Özgül, 2000). Çalışma alanında bulunan jeolojik birimler, litolojik özelliklerine göre gözenekli akifer, karstik akifer, akitard birimler ve akifüj birimler olarak ayırtlanmış. Çalışma alanında kireçtaşlarından oluşan Kumalar Formasyonu Kireçtaşı üyesi, Karahasan Formasyonu, Sütlaçtepe Formasyonu, Afyonluk Formasyonu ve Bakırdağ Formasyonu karstik akifer olarak tanımlanmıştır. Kumalar Formasyonu ve bu formasyona ait volkanik üyesi, İlyası ıormasyonu, Kocadere Formasyonu, Karaçal Formasyonu, Ortatepe Formasyonu ve Koyuntepe Formasyonu bünyelerinde sınırlı yeraltısuyu bulundurmaları sebebiyle yarı geçirimli birimler oluşturmaktadırlar. Bölgede yüzeyleyen filiş karakterindeki Karataş Formasyonu (Akifüj-1), ofiyolitik melanj (Akifüj-2), Yalnızağaç Formasyonu (Akifüj-3) ve Afyon Metamorfikleri (Akifüj-3) geçirimsiz birimler olarak sınıflandırılmıştır. Çaıışma alanının hidrojeoloji haritası Şekil 3'de verilmiştir.

Şuhut Ovası'nda yeraltısuyu açısından önemli litolojik birimler; Kuvaterner alüvyon ve yamaç molozu içerisindeki kum ve çakıl serileri, karbonatlı kayaçlar, Neojen tüfleri ve aglomeralarıdır. Ovada yeraltısuyunu bünyesinde bulunduran ve gözenekli akifer olarak tanımlanan alüvyon ve yamaç molozları, kum, çakıl, killi kum, kumlu çakıl ve killi birimlerden oluşmaktadır. Alüvyonun kalınlığı ova kenarlarında 10-30 metre, ovanın orta kesimlerinde ise 100-150 metredir. Ovada yeraltısuyu kuyularının tamamı alüvyon birim üzerinde bulunmaktadır. Genel olarak alüvyon biriminin altında tüflü seviyeler bulunmakta olup sadece ovanın kuzey kesimlerinde bulunan sondajlara ait loglarda kireçtaşı seviyeleri gözlenmektedir. ÇaIışma alanının doğu kesimlerinde yer yer gözlenen kireçtaşı dokanaklarından düşük debili kaynak çıkışları gözlenmektedir. Ayrıca, batı kesimlerdeki volkanik birimlerin kırık çatlaklarından boşalan ve mevsimlik akıma sahip kaynak çıkışları da bulunmaktadır (Mülga Orman ve Su İşleri Bakanlığı, 2013). Çalışma alanında yeraltısuyu potansiyelinin büyük kısmı alüvyonlar ve gölsel çökellerde bulunmaktadır. Akifer beslenimi, akifer yüzeyine düşen yağışın yanı sıra volkanikler ve karbonatı birimlerden yanal beslenim olarak gerçekleşir. Şuhut (Kali) Deresi'nin yeraltısuyunu beslemesi söz konusudur (Sargın, 2020). 
Afyonkarahisar Şuhut Ovası Yeraltısularının Hidrojeokimyasal İncelemesi

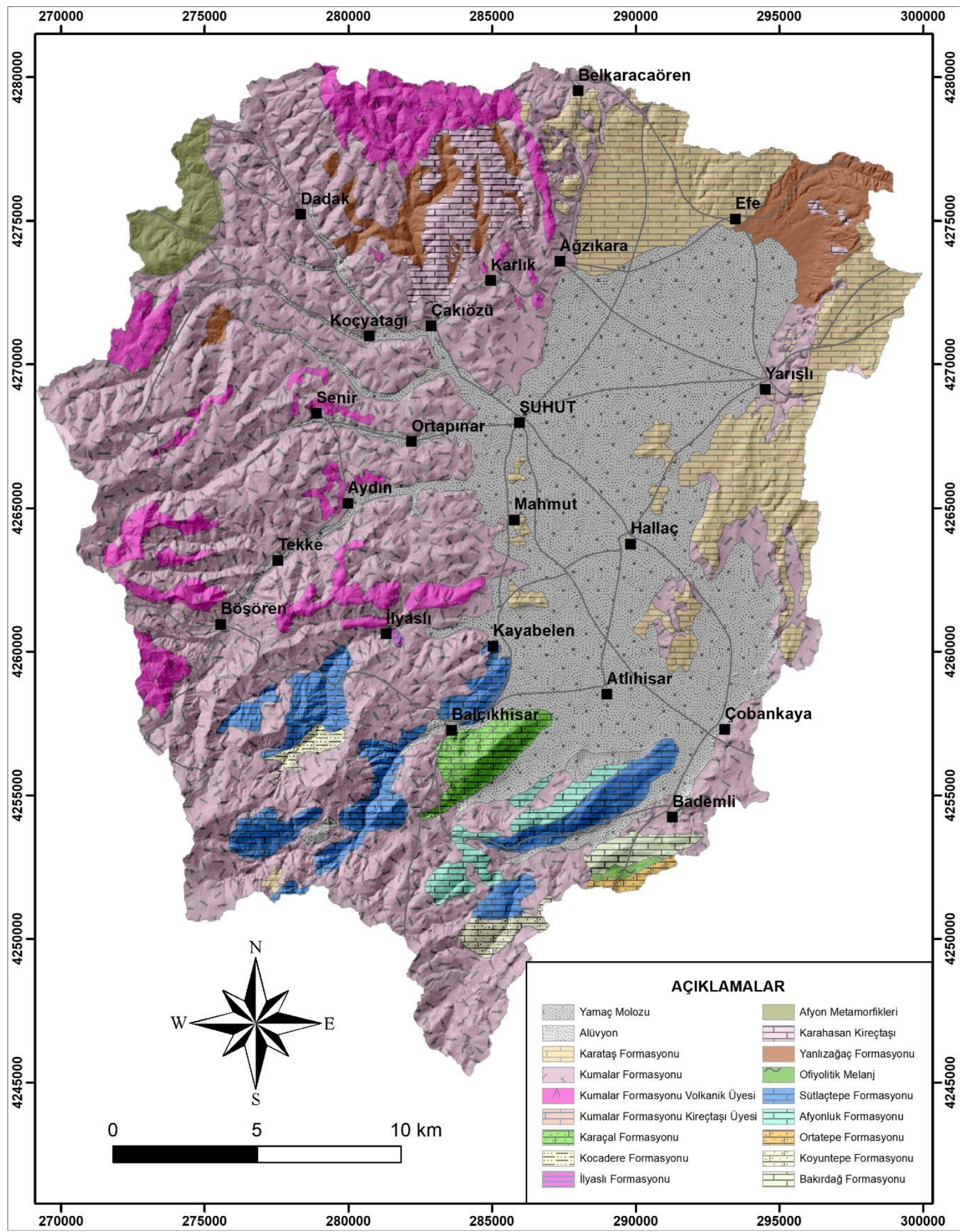

Şekil 2. Çalışma alanının jeoloji haritası

Ovada yeraltısuyu kuyularının tamamı alüvyon birim üzerinde bulunmaktadır. Bölgede yeraltısuyu seviyesini ve yeraltısuyu akım yönünü belirleyebilmek amacıyla mevcut sondaj kuyularında Mayıs (2019) döneminde yeraltısuyu seviye ölçümleri gerçekleştirilmiş ve bölgenin 
yeraltısuyu seviye haritası hazırlanmışır (Şekil 3). Ovadaki kuyuların bir kısmı tahrip edildiğinden bir kısmına ise dalgıç pompa yerleştirildiğinden yeraltısuyu seviye ölçümleri yapılamamıştır. Bölgede yeraltısuyu derinlikleri 7,27- 27,4 m arasında değişmekte olup yeraltısuyu seviyeleri ise $1085 \mathrm{~m}$ ile $1134 \mathrm{~m}$ arasındadır. Ovanın kuzey kesimlerinde yeraltısuyu seviyesi daha düşüktür. Şekil 3'de verilen hidrojeoloji haritası üzerinde yeralan yeraltısuyu seviye eğrileri incelendiğinde Şuhut Ovasında yeraltısuyu akım yönünün Ovanın kuzey kesimlerinde güneye doğru, Şuhut ve Mahmut civarında doğuya doğru, Altınhisar ve Çobankaya civarında ise kuzeydoğuya doğru olduğu belirlenmiştir. Ayrıca, yeraltısuyu yüzeyinin düzgün bir morfolojiye sahip olduğu görülmektedir. Seviye eğrileri genel olarak birbirine paralel ve gidişleri düzgündür. Bu durum akifer ortamın (alüvyon birim) izotrop ve homojen olduğunu göstermektedir. Bunun yanı sıra Şuhut ovası içme suları \%93,4'ü alüvyon ortamdan, \%2,4'ü Afyon Metamorfikleri içerisinde yer alan Kumalar Formasyonu ve Afyon Metamorfikleri ile \%4,3'ü Karataş Formasyonu'ndan sağlanmaktadır (Sargın, 2020).

\section{Yeraltısuyu Hidrojeokimyası}

Yeraltısuyunun kimyasal özellikleri akifer birimlerin özelliklerine ve antropojenik girdilere bağlı olarak değişim göstermektedir. Mayıs (2019) döneminde, bölgede bulu- nan yeraltısuyu kuyularından alınan su örneklerinin sıcaklık ( $\left.{ }^{\circ} \mathrm{C}\right), \mathrm{pH}, \mathrm{El}, \mathrm{TÇM}, \mathrm{Ca}, \mathrm{Mg}, \mathrm{Na}, \mathrm{K}, \mathrm{HCO}_{3}, \mathrm{SO}_{4}, \mathrm{Cl}$, $\mathrm{NO}_{3}$ ve $\mathrm{CO}_{3}$ gibi fizikokimyasal parametrelerine ve majör iyonlarına ait ölçüm ve analiz sonuçları Tablo 1'de sunulmuştur. Bunun yanısıra örneklerin alansal dağılım haritaları alüvyon akifer içerisindeki sondaj kuyularından alınan örneklerin analiz sonuçlarına göre hazırlanmıştır (Şekil 4-6).

Çalışma alanındaki su örneklerinin sıcaklık değerleri $11^{\circ} \mathrm{C}$ ile $18,7^{\circ} \mathrm{C}$ arasında değişmektedir. Yeraltısularının $\mathrm{pH}$ değerleri ise 7.13 ile 8.55 arasında olup ortalama $7.65 \mathrm{pH}$ değeri ölçülmüştür (Tablo 1, Şekil 4a ve 4b). Buna göre çalışma alanında ovanın kuzey kesimlerinden alınan su örneklerinin karbonatı kayaçlarla ilişkili olarak $\mathrm{pH}$ değerleri daha yüksek iken genel olarak tüm sular "bazik karakterli sular" sınıfında yer almaktadır. Suların sıcaklığı ve iyon bolluk miktarına göre değişim gösteren elektriksel iletkenlik (EI) değeri su örneklerinde 102,6 ile 1169,00 $\mu \mathrm{S} / \mathrm{cm}$ arasındadır. Su örneklerindeki yüksek El değerleri, çalışma alanındaki yeraltısularının iyonlarca zenginleştiğini göstermektedir. Ayrıca yeraltısuyu örneklerinin toplam çözünmüş madde (TÇM) değerleri 65.66 ile $748.16 \mathrm{mg} / \mathrm{L}$ arasında değişmektedir. Çalışma alanında en yüksek El ve TÇM değerleri, ovanın orta kesiminde bulunan Hallaç ve Mahmut bölgelerindeki S16, S19 ve S21 nolu sondaj kuyularından alınan örneklerde ölçülmüştür (Şekil 4c ve 4d).

Tablo 1. Yeraltısuyu örneklerine ait kimyasal parametrelerin değerleri

\begin{tabular}{|c|c|c|c|c|c|c|c|c|c|c|c|c|c|c|}
\hline Örn. No & Örn. Tipi & $\begin{array}{c}\text { Sicaklık } \\
{ }^{\circ} \mathrm{C}\end{array}$ & $\mathrm{pH}$ & $\begin{array}{c}\mathbf{E I} \\
(\mu \mathrm{S} / \mathrm{cm})\end{array}$ & \begin{tabular}{|c|} 
TÇM \\
(mg/L)
\end{tabular} & $\begin{array}{c}\mathrm{Ca} \\
(\mathrm{mg} / \mathrm{L})\end{array}$ & \begin{tabular}{|c|}
$\mathbf{M g}$ \\
$(\mathrm{mg} / \mathrm{L})$
\end{tabular} & $\begin{array}{c}\mathrm{Na} \\
(\mathrm{mg} / \mathrm{L})\end{array}$ & $\begin{array}{c}\mathbf{K} \\
(\mathrm{mg} / \mathrm{L})\end{array}$ & $\begin{array}{l}\mathrm{HCO}_{3} \\
(\mathrm{mg} / \mathrm{L})\end{array}$ & $\begin{array}{c}\mathrm{SO}_{4} \\
(\mathrm{mg} / \mathrm{L})\end{array}$ & $\begin{array}{c}\mathrm{Cl} \\
(\mathrm{mg} / \mathrm{L})\end{array}$ & \begin{tabular}{|c|}
$\mathrm{NO}_{3}$ \\
$(\mathrm{mg} / \mathrm{L})$
\end{tabular} & $\begin{array}{c}\mathrm{CO}_{3} \\
(\mathrm{mg} / \mathrm{L})\end{array}$ \\
\hline S1 & ${ }^{*} \mathrm{~S} . \mathrm{K}$ & 13.20 & 8.49 & 341.00 & 214.83 & 51.62 & 9.67 & 6.08 & 4.10 & 207.27 & 4.01 & 3.70 & 2.31 & 7.60 \\
\hline S2 & S.K & 11.50 & \begin{tabular}{|l|}
7.47 \\
\end{tabular} & 102.60 & 65.66 & 11.14 & 3.54 & 4.10 & 3.42 & 44.40 & 17.85 & 2.28 & 1.01 & 1.99 \\
\hline S3 & S.K & 12.90 & 7.95 & 217.80 & 139.39 & 28.69 & 3.69 & 5.71 & 5.68 & 87.23 & 23.09 & 2.83 & 1.53 & 1.99 \\
\hline S4 & S.K & 11.00 & 8.55 & 176.60 & 113.02 & 21.16 & 5.05 & 4.47 & 3.62 & 85.52 & 8.75 & 3.13 & 2.80 & 1.99 \\
\hline S5 & S.K & 14.70 & 7.94 & 329.00 & 210.56 & 36.07 & 17.69 & 6.44 & 3.81 & 193.37 & 5.79 & 2.77 & 4.17 & 1.99 \\
\hline S6 & S.K & 14.40 & 7.69 & 420.00 & 268.80 & 64.52 & 11.46 & 9.28 & 2.21 & 234.97 & 10.85 & 5.81 & 16.51 & 1.99 \\
\hline S7 & S.K & 15.00 & 7.81 & 429.00 & 274.56 & 70.70 & 1.45 & 4.69 & 9.33 & 232.53 & 24.91 & 2.59 & 13.38 & 1.99 \\
\hline S8 & S.K & 12.90 & 7.44 & \begin{tabular}{|l|}
580.00 \\
\end{tabular} & 371.20 & 55.87 & 25.17 & 15.21 & 12.63 & 247.05 & 40.11 & 18.43 & 18.76 & 1.99 \\
\hline S9 & S.K & 14.00 & 7.5 & 499.00 & 319.36 & 81.60 & 7.77 & 3.59 & 3.05 & 272.42 & 5.31 & 1.75 & 24.48 & 1.99 \\
\hline $\mathrm{S} 10$ & S.K & 17.70 & 7.61 & 433.00 & 277.12 & 73.42 & 4.66 & 8.43 & 4.13 & 222.40 & 19.77 & 6.26 & 14.26 & 1.99 \\
\hline S11 & S.K & 15.30 & 7.43 & 303.00 & 193.92 & 29.57 & 10.83 & 12.49 & 7.05 & 118.70 & 32.65 & 6.58 & 0.63 & 1.99 \\
\hline $\mathrm{S} 12$ & S.K & 14.50 & 7.9 & 530.00 & 333.90 & 54.10 & 25.46 & 8.04 & 8.99 & 331.35 & 7.87 & 6.18 & 2.71 & 1.99 \\
\hline $\mathrm{S} 13$ & S.K & 17.80 & 7.13 & \begin{tabular}{|l|}
235.00 \\
\end{tabular} & 150.40 & 24.92 & 4.90 & 9.90 & 5.29 & 83.57 & 32.49 & 2.60 & 0.20 & 1.99 \\
\hline $\mathrm{S} 14$ & S.K & 12.00 & 7.81 & 455.00 & 291.20 & 61.96 & 11.51 & 9.59 & 7.05 & 208.62 & 63.07 & 4.75 & 11.05 & 1.99 \\
\hline $\mathrm{S} 15$ & S.K & 17.00 & 7.21 & 580.00 & 371.20 & 94.74 & 11.27 & 10.40 & 8.42 & 294.26 & 45.50 & 10.14 & 1.41 & 1.99 \\
\hline S16 & S.K & 15.30 & 7.17 & \begin{tabular}{|l|}
1169.00 \\
\end{tabular} & 748.16 & 169.93 & 39.12 & 39.25 & 18.70 & 495.32 & 177.33 & 40.46 & 74.92 & 1.99 \\
\hline S17 & S.K & 14.50 & 7.82 & 367.00 & 234.88 & 54.98 & 5.73 & 11.64 & 4.81 & 197.88 & 9.71 & 5.46 & 8.52 & 1.99 \\
\hline $\mathrm{S} 18$ & S.K & 18.00 & 7.83 & 543.00 & 347.52 & 81.92 & 9.91 & 11.09 & 5.65 & 273.76 & 9.76 & 16.23 & 47.49 & 1.99 \\
\hline $\mathrm{S} 19$ & S.K & 12.00 & 7.18 & \begin{tabular}{|l|}
777.00 \\
\end{tabular} & 497.28 & 102.12 & 21.67 & 12.81 & 6.96 & 288.40 & 105.27 & 23.76 & 71.52 & 1.99 \\
\hline $\mathrm{S} 20$ & S.K & 17.00 & 7.85 & \begin{tabular}{|l|}
425.00 \\
\end{tabular} & 272.00 & 58.91 & 11.51 & 10.27 & 3.62 & 225.94 & 12.03 & 5.40 & 15.12 & 1.99 \\
\hline $\mathrm{S} 21$ & S.K & 16.70 & 7.44 & \begin{tabular}{|l|}
888.00 \\
\end{tabular} & 586.08 & 98.11 & 49.47 & 11.82 & 9.46 & 373.80 & 113.53 & 15.15 & 38.24 & 1.99 \\
\hline $\mathrm{S} 22$ & S.K & 13.10 & 7.44 & 554.00 & 354.56 & 95.06 & 12.63 & 4.80 & 6.78 & 311.83 & 29.26 & 5.37 & 11.61 & 1.99 \\
\hline $\mathbf{S 2 3}$ & S.K & 18.70 & 7.65 & 665.00 & 425.60 & 96.35 & 19.63 & 16.38 & 8.12 & 241.07 & 122.65 & 8.46 & 6.81 & 1.99 \\
\hline
\end{tabular}


Afyonkarahisar Şuhut Ovası Yeraltısularının Hidrojeokimyasal İncelemesi

\begin{tabular}{|c|c|c|c|c|c|c|c|c|c|c|c|c|c|c|}
\hline S24 & S.K & 14.90 & 7.84 & 327.00 & 215.82 & 41.12 & 9.76 & 10.58 & 1.66 & 168.97 & 9.31 & 6.52 & 16.61 & 1.99 \\
\hline S25 & S.K & 11.20 & 7.64 & 409.00 & 261.76 & 52.26 & 11.66 & 9.48 & 4.67 & 117.12 & 77.59 & 5.80 & 3.42 & 1.99 \\
\hline S26 & S.K & 17.60 & 7.48 & 688.00 & 440.32 & 87.53 & 23.32 & 10.46 & 4.90 & 363.07 & 19.84 & 14.91 & 88.08 & 1.99 \\
\hline S27 & S.K & 14.80 & 7.33 & 442.00 & 282.88 & 36.15 & 6.65 & 16.50 & 69.15 & 202.27 & 32.88 & 12.66 & 31.43 & 1.99 \\
\hline
\end{tabular}

( ${ }^{*}$ S.K: sondaj kuyusu)

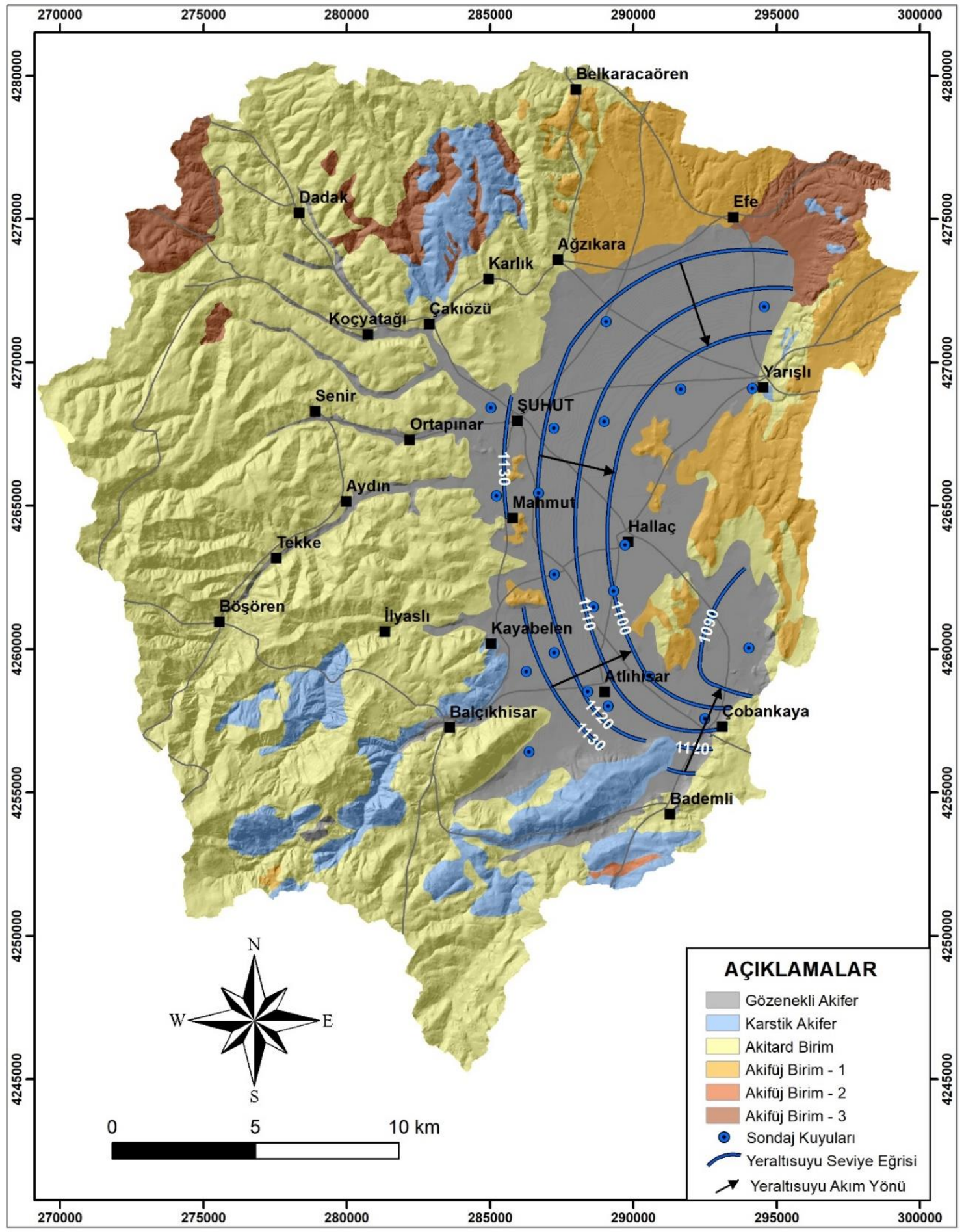

Şekil 3. Çalışma alanının hidrojeoloji haritası 


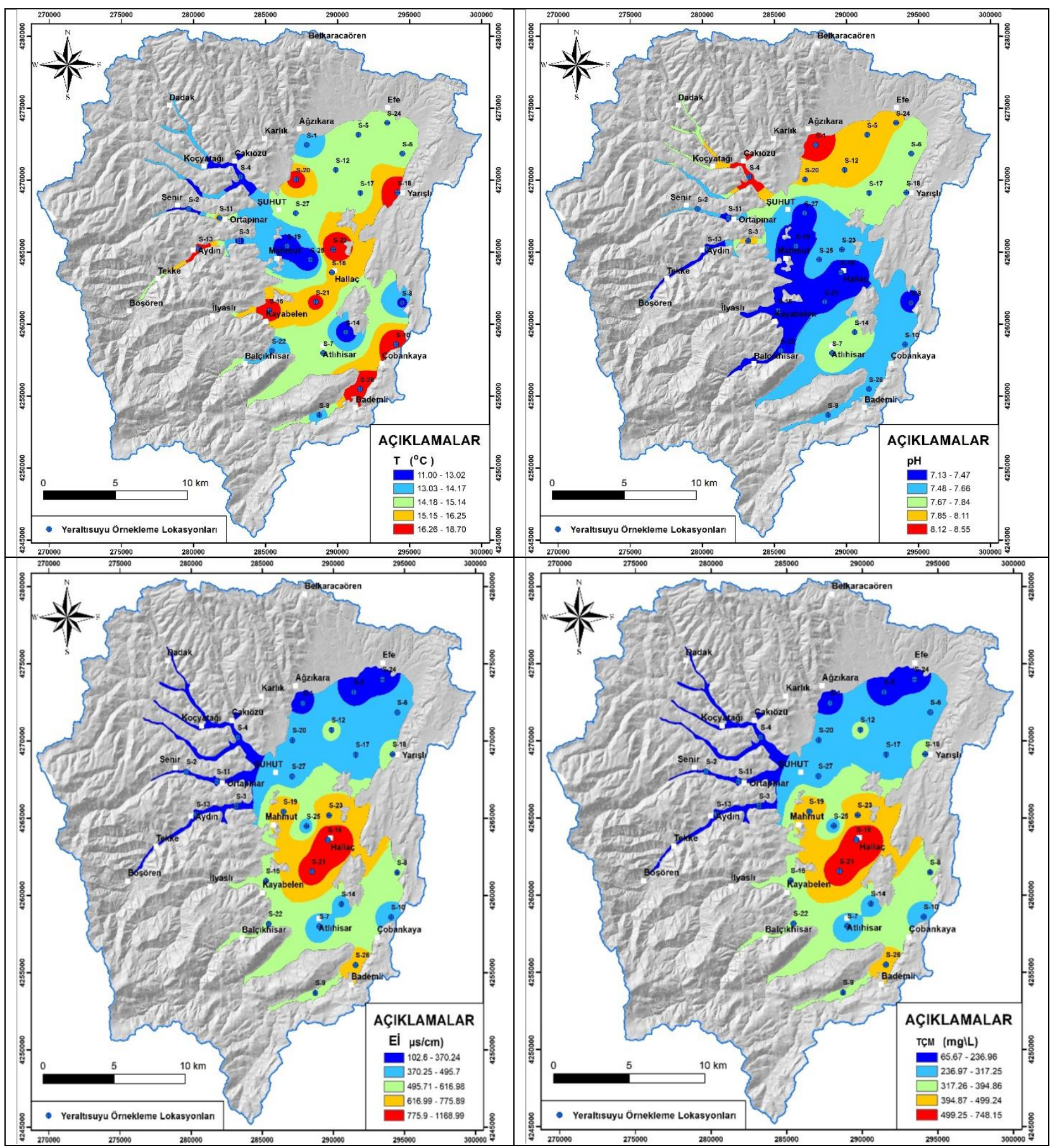

Şekil 4. Yeraltısuyu örneklerinin (a) sıcaklık, (b) pH, (c) El ve (d) TÇM parametrelerine ait dağılım haritaları

Yeraltısuyu örneklerinin majör anyon ve katyonlarına ait analiz sonuçları Tablo 1'de verilmiştir. Elde edilen verilere göre genel olarak sulardaki anyon ve katyon bolluk dizilimleri $\mathrm{HCO}_{3}{ }^{-2}>\mathrm{SO}_{4}{ }^{-2}>\mathrm{Cl}^{-}>\mathrm{CO}_{3}{ }^{-2}$

$\mathrm{Ca}^{+2}>\mathrm{Mg}^{+2}>\mathrm{Na}^{+}>\mathrm{K}^{+}$, seklindedir. Ancak bazı yeraltısuyu örneklerinde (S2, S3, S7, S10, S13, S17, S18, S24, S27)
$\mathrm{Na}^{+}$iyonlarının miktarı $\mathrm{Mg}^{+2}$ iyonlarının miktarından fazladır ve katyon bolluk dizilimleri $\mathrm{Ca}^{+2}>\mathrm{Na}^{+}>\mathrm{Mg}^{+2}>\mathrm{K}^{+}$şeklindedir.

Anyon bolluk dizilimi ise sadece $\mathrm{S} 18$ numaralı su örneğinde $\mathrm{HCO}_{3}{ }^{-2}>\mathrm{Cl}>\mathrm{SO}_{4}{ }^{-2}>\mathrm{CO}_{3}{ }^{-2}$ şeklinde değişmektedir. $\mathrm{Bu}$ örneğin $\mathrm{Cl}$ içeriği, $\mathrm{SO}_{4}$ içeriğinden daha yüksektir. 
Yeraltısularında bulunan hakim iyonlara ait dağııım haritaları hazırlanmış ve Şekil $5 a, 5 b, 5 c$ ve 5 d'de sunulmuştur. Dağılım haritalarında görüldüğü üzere, $\mathrm{Ca}, \mathrm{Mg}, \mathrm{Na}$,
$\mathrm{K}$ değerlerinin ovanın orta kesimlerinden alınan su örneklerinde, kıyı kesimlerden alınan örneklere kıyasla daha yüksek olduğu belirlenmiştir.

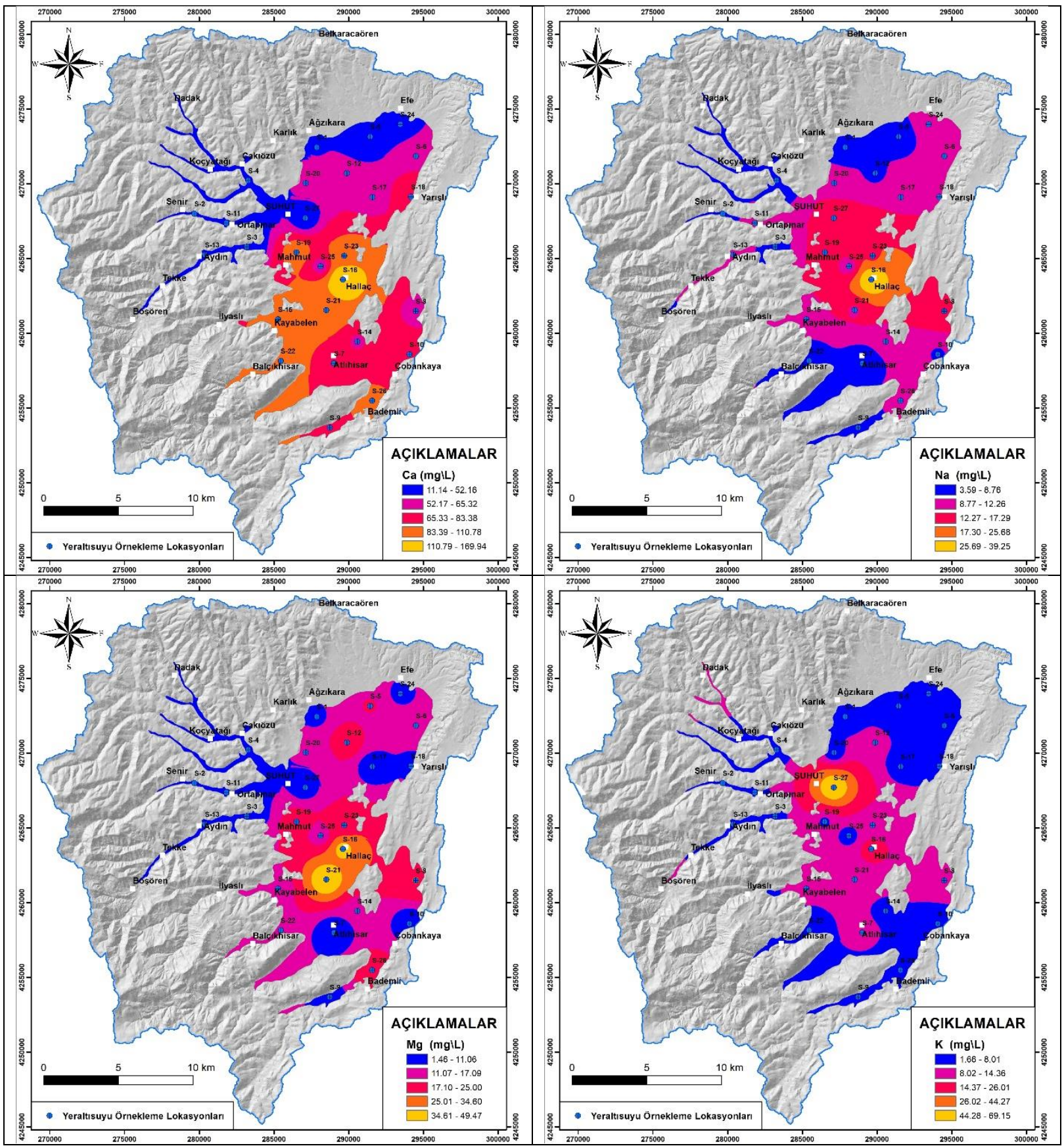

Şekil 5. Yeraltısuyu örneklerinin (a) $\mathrm{Ca}$, (b) $\mathrm{Na}$, (c) Mg ve (d) K parametrelerine ait dağılım haritaları

Bu bölgelerde alüvyon kalınlığının fazla olması ve yeraltısuyu hareket yönünün bu bölgeye doğru olması iyon zenginleşmesini artırmaktadır. K iyonunun sadece 27 nolu su örneğinde oldukça yüksek olması, o bölgede antropojenik bir kirletici etkisinin varlığını düşündürmektedir. $\mathrm{Ca}$, $\mathrm{Na}$ ve $\mathrm{Mg}$ iyonları genel olarak benzer su örneklerinde yüksek ölçülmüştür. $\mathrm{HCO}_{3}, \mathrm{SO}_{4}, \mathrm{Cl}$ ve $\mathrm{NO}_{3}$ parametrelerine ait dağılım haritaları ise Şekil $6 a, 6 b, 6 c$ ve 6 d'de verilmiştir. 


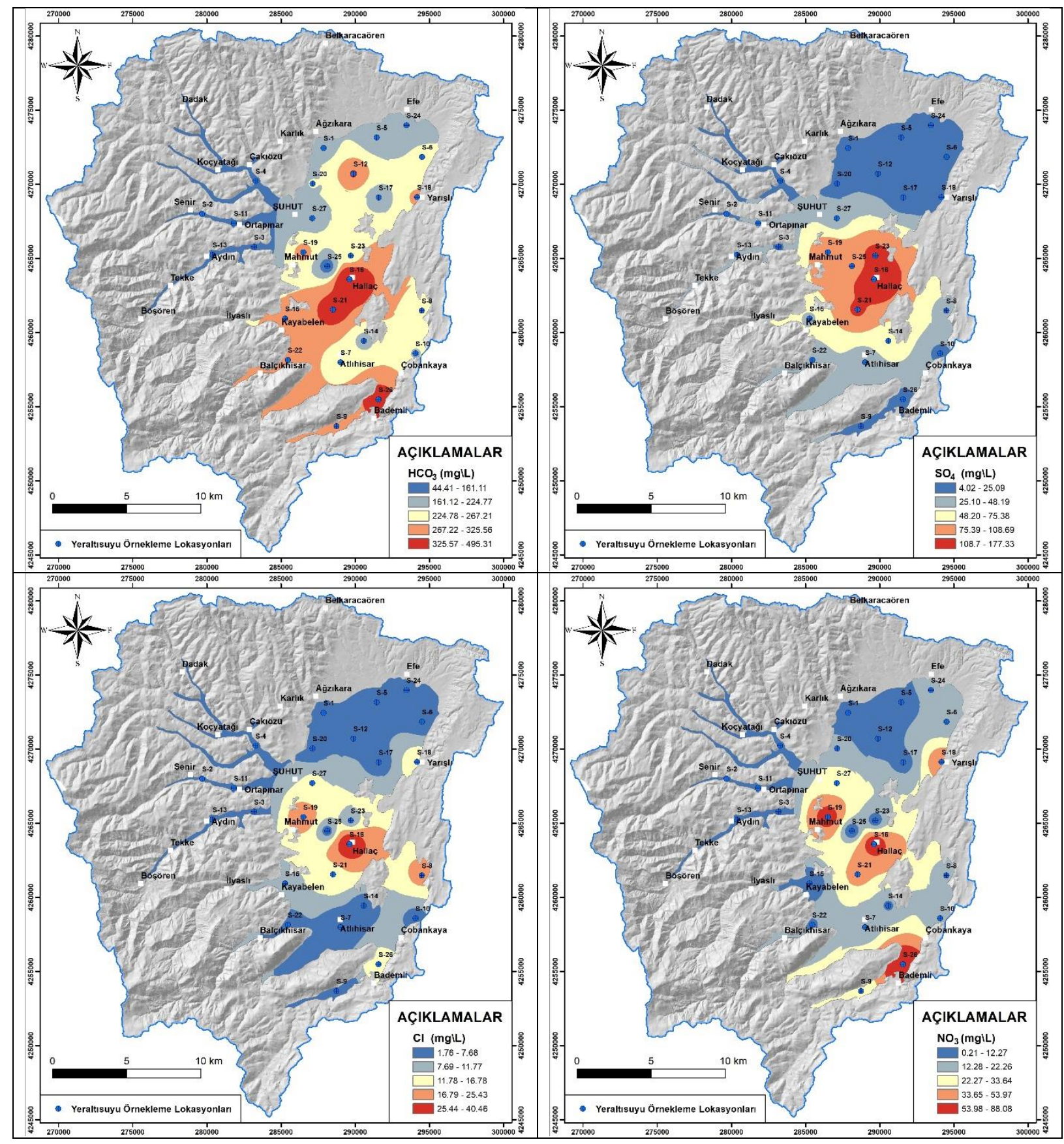

Şekil 6. Yeraltısuyu örneklerinin (a) $\mathrm{HCO}_{3}$, (b) $\mathrm{SO}_{4}$,

(c) $\mathrm{Cl}$ ve (d) $\mathrm{NO}_{3}$ parametrelerine ait dağılım haritaları

Anyon konsantrasyonlarının da katyonlar ile benzer şekilde ovanın orta kesimlerindeki kuyularda göreceli yüksek miktarlarda olduğu görülmektedir. Ayrıca, su örneklerinin $\mathrm{NO}_{3}$ konsantrasyonları Hallaç ve Mahmut bölgelerinin yanı sıra Bademli civarında da oldukça yüksek miktarlarda (>50 mg/L) ölçülmüştür. Bu durumun bölgedeki yoğun tarımsal faaliyetlerle ilişkili olduğu düşünülmektedir.

\section{Yeraltısularının Hidrojeokimyasal Fasiyes Özellikleri ve Kontrol mekanizması}

Yeraltısularının kimyasal gelişimini ve kökenini belirlemede kullanılan önemli araçlardan biri hidrojeokimyasal fasiyesdir. Yeraltısuyu örneklerinde baskın majör iyonlar (katyonlar ve anyonlar) tarafından belirlenen hidrojeokimyasal fasiyes, su kimyasındaki benzerlik ve farklılıkları göstermek için kullanılmaktadır. Çalışma alanındaki 
yeraltısularının hidrojeokimyasal fasiyesi, majör katyonlar $(\mathrm{Ca}, \mathrm{Mg}, \mathrm{Na}$ ve $\mathrm{K})$ ve anyonlar $\left(\mathrm{HCO}_{3}, \mathrm{SO}_{4}\right.$ ve $\left.\mathrm{Cl}\right)$ kullanılarak Piper Diyagramı (Piper, 1944) ile değerlendirilmiştir (Şekil 7).

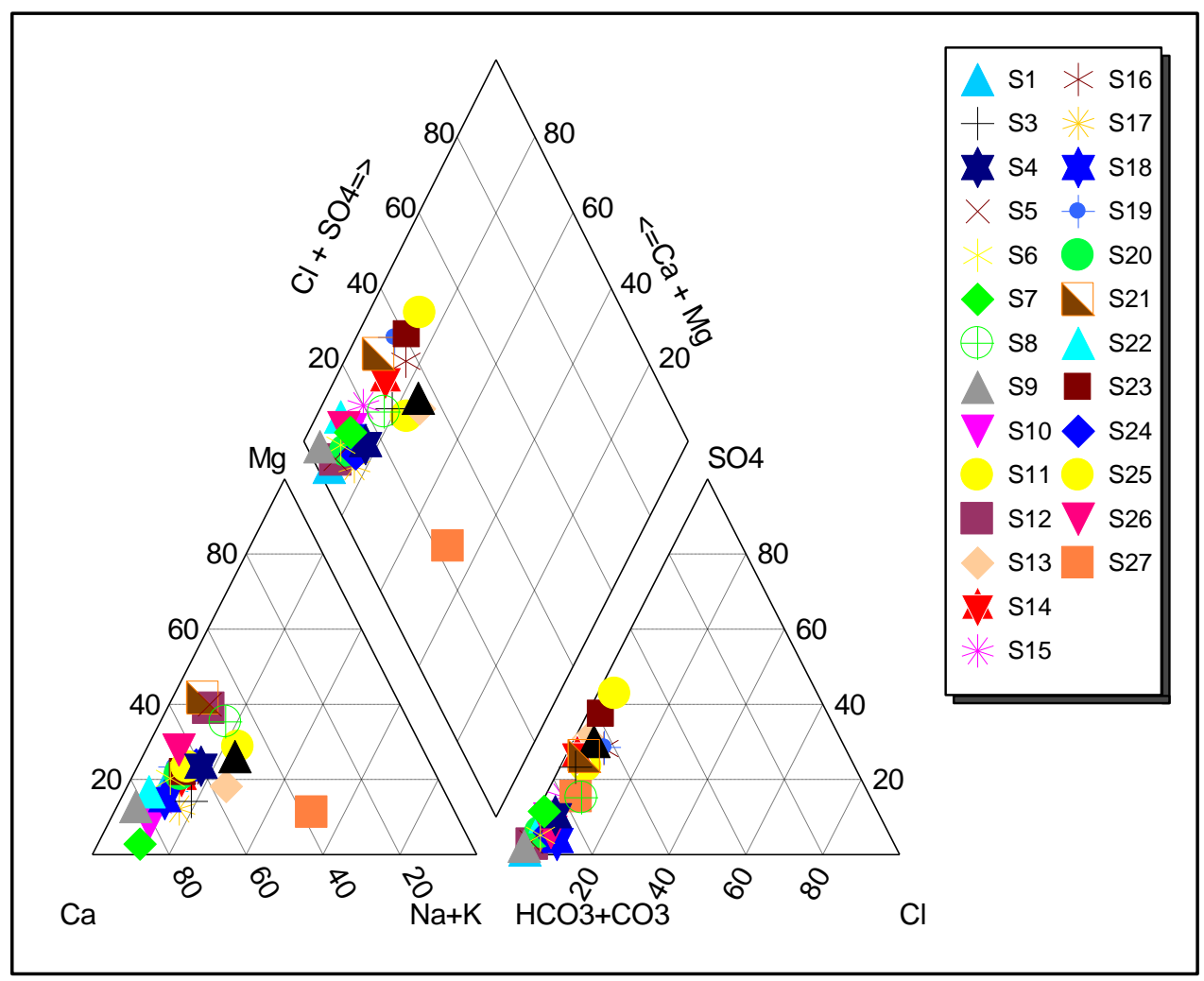

Şekil 7. Piper diyagramı, Mayıs-2019

Piper Diyagramı'na göre, çalışma alanında Ca-Mg$\mathrm{HCO}_{3}$ ve $\mathrm{Ca}-\mathrm{HCO}_{3}$ su tipi hakim olup, alkali toprak elementlerinin $(\mathrm{Ca}+\mathrm{Mg})$, alkali elementlere $(\mathrm{Na}+\mathrm{K})$ göre daha fazla olduğu, zayıf asit köklerinin $\left(\mathrm{CO}_{3}+\mathrm{HCO}_{3}\right)$ güçlü asit köklerinden $\left(\mathrm{SO}_{4}+\mathrm{Cl}\right)$ fazla olduğu, karbonat sertliği \%50'den fazla olan suları temsil etmektedir. Yeraltısularının kayaçlar ve antropojenik kirleticilerle etkileşim süresi, bölgedeki farklı su türlerinin oluşumunda önemli rol oynamaktadır.

Yeraltısularında çözünmüş iyonların kaynağı hakkındaki bilgilere Gibbs diyagramları ile erişilebilir (Gibbs, 1970). Bu diyagramlar $(\mathrm{Na}+\mathrm{K})$ / $(\mathrm{Na}+\mathrm{K}+\mathrm{Ca})$ karşı TÇM (Gibbs
Oranı I) ve $\mathrm{Cl} /\left(\mathrm{Cl}+\mathrm{HCO}_{3}\right)$ karşı TÇM (Gibbs Oranı II) grafiğidir. Gibbs diyagramları çoğunlukla suların kimyasal bileşiminin gelişiminde rol oynayan yağış, kayaç ve buharlaşma hakimiyeti gibi kimyasal süreçleri belirlemek için kullanılır. Bölgedeki suların kimyasal yapısını etkileyen faktörleri belirlemek için hazırlanan Gibbs diyagramları Şekil 8'de sunulmuştur. Buna göre, çalışma alanındaki hemen hemen tüm su örneklerinin kayaç baskın bölgeye düştüğü görülmektedir. Bu durum, su kimyasını kontrol eden ana mekanizmanın, kayaç yapıcı minerallerin kimyasal ayrışması olduğunu göstermektedir (Laxmankumar ve ark., 2019). 


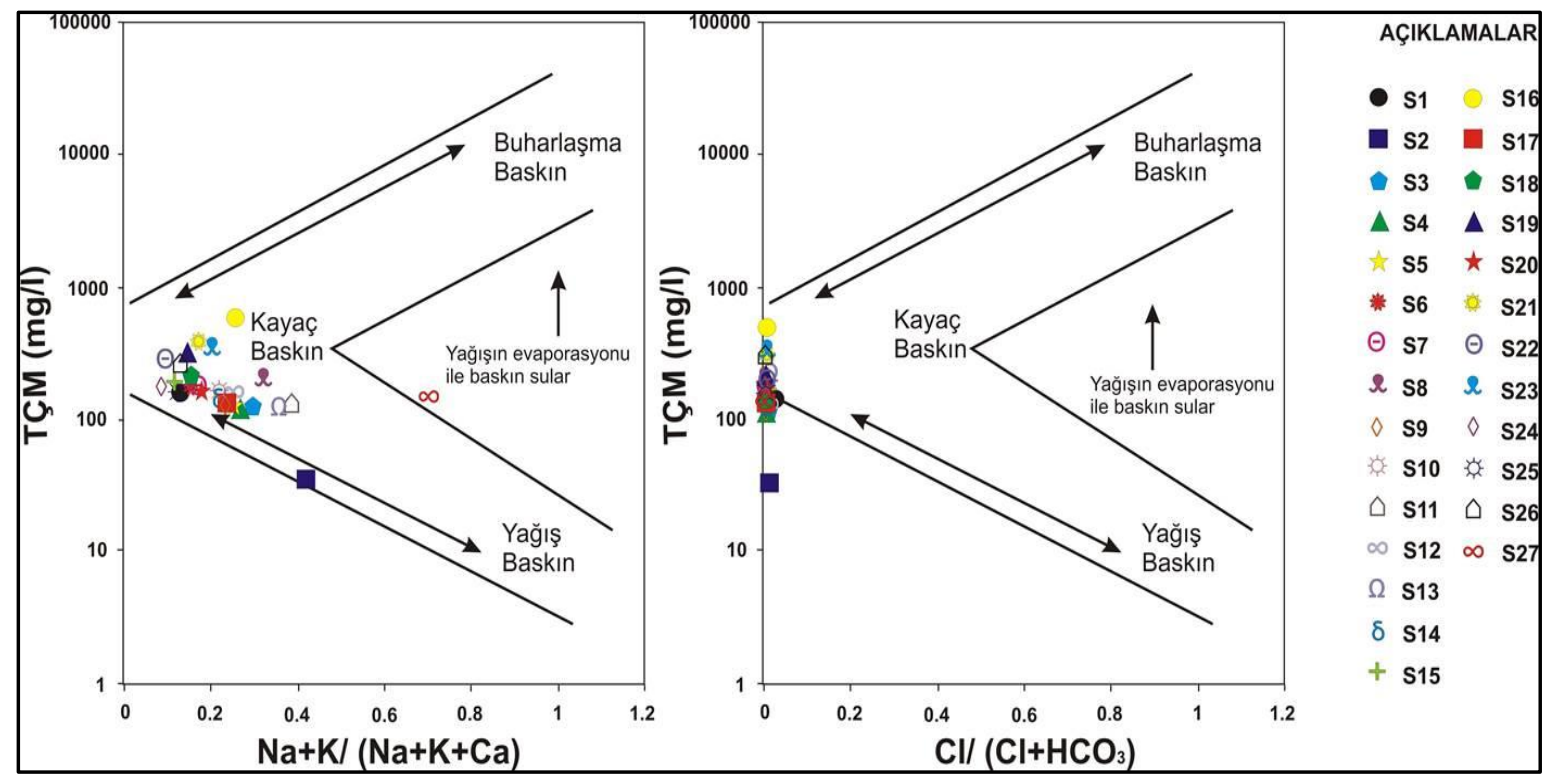

Şekil 8. Gibss diyagramı, Mayıs-2019

Kayaç baskın alanına düşen örneklerin iyon içeriğine bağlı olarak kayaç kimyası ile yeraltısuyu kimyası arasında bir etkileşim söz konusudur. Çalışma alanındaki alüvyon ortama ait su örnekleri genel olarak karstik akiferi (Kumalar Formasyonu Kireçtaşı üyesi, Karahasan Formasyonu, Sütlaçtepe Formasyonu, Afyonluk Formasyonu ve Bakırdağ Formasyonu) oluşturan kalkerli kayaçlar ile etkileşim halindedir. Bu bağlamda yeraltısularının akım yönüne bağıı olarak ovada karstik akiferlerle temas sonrası yanal akımla alüvyon ortama taşındığı ve baskın su tiplerinin söz konusu kayaç-su etkileşimi sonucunda geliştiği görülmektedir. Sadece 27 nolu su örneği yağışın evaporasyonu ile baskın sular alanında yer almaktadır.

\section{Yeraltısularının Hidrojeokimyasal Süreçleri}

Yeraltısularında major iyon konsantrasyonları, akifer sistemindeki hidrojeokimyasal süreçlerle ilişkili olarak gelişim göstermektedir (Lakshmanan ve ark., 2003). ÇaIışma alanındaki yeraltısularında katyonlardan kalsiyum, magnezyum ve sodyum; anyonlardan ise bikarbonat ve sülfat iyonları baskındır. Bu iyonların bolluk durumları, akifer sistemindeki hidrojeokimyasal süreçlerle ilgilidir. Bu süreçleri açıklamak için farklı diyagramlar hazırlanmış ve yorumlar bu diyagramlar üzerinden yapılmıştır. Genel olarak sularda karbonatlar ve silikatlar mineralizasyonun ana kaynaklarıdır. $\left(\mathrm{Ca}^{2+}+\mathrm{Mg}^{2+}\right)$ ve $\left(\mathrm{HCO}_{3}\right.$ $+\mathrm{SO}_{4}{ }^{2-}$ ) diyagramı yeraltısularındaki baskın ayrışma tipini göstermektedir. Diyagram üzerinde (1:1) çizgisi boyunca düşen noktalar karbonat ayrışmasının; 1:1 çizgisinin altındaki noktalar ise silikat ayrışmasının bir göstergesidir (Kumar ve ark., 2009). Şekil 9'e göre, çalışma alanındaki yeraltısularının kimyasal gelişiminde karbonat ayrışması hakim rol oynamaktadır. 
Afyonkarahisar Şuhut Ovası Yeraltısularının Hidrojeokimyasal İncelemesi

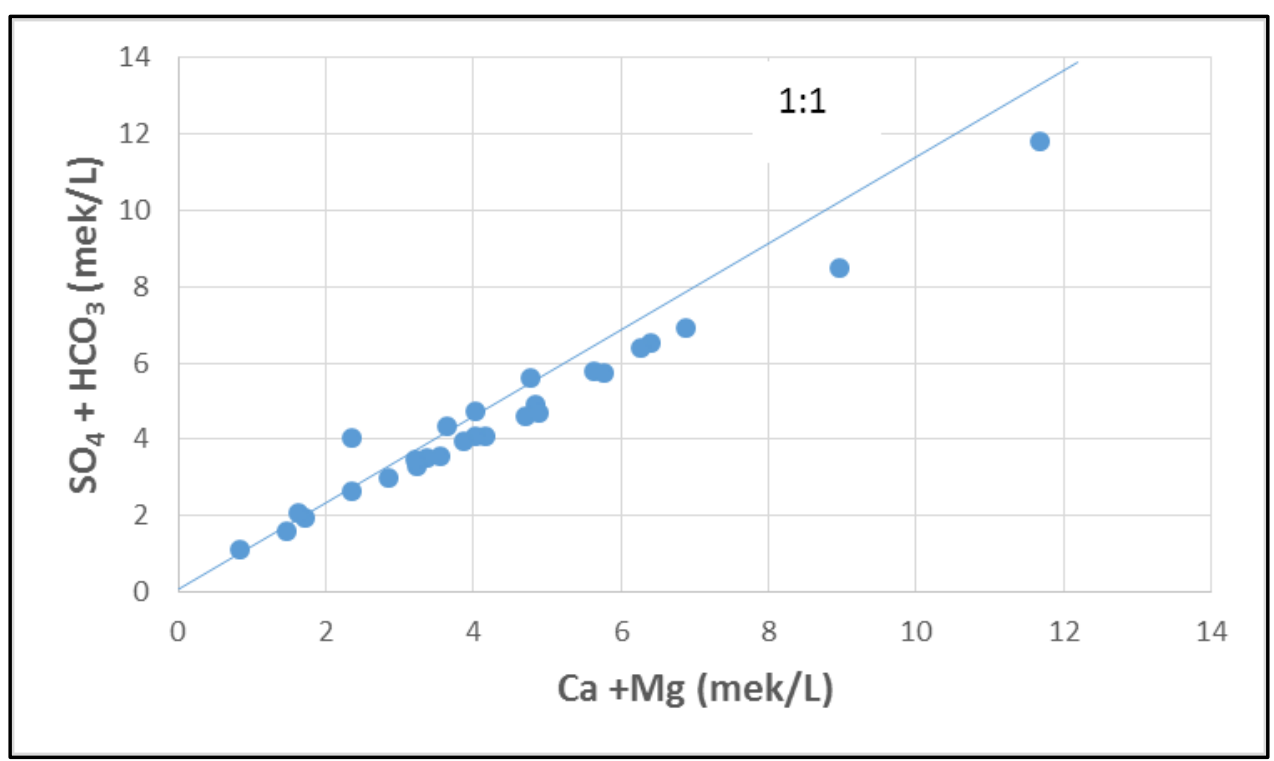

Şekil 9. Yeraltısularının $\mathrm{Ca}^{2+}+\mathrm{Mg}^{2+}$ ve $\mathrm{HCO}_{3}{ }^{-}+\mathrm{SO}_{4}{ }^{2-}$ diyagramı

Yeraltısularının $\mathrm{Ca}^{2+} / \mathrm{Mg}^{2+}$ oranı kalsit ve dolomit çözünümünü göstermektedir. Molar $\mathrm{Ca}^{2+} / \mathrm{Mg}^{2+}$ oranı 1'den yüksek ise kalsit çözünmesi daha etkindir. Oran 2'den büyükse, Ca ve Mg iyonlarının varlığı silikat minerallerinin ayrışmasından kaynaklanmaktadır. Çalışma alanındaki yeraltısuyu örneklerinin tamamında $\mathrm{Ca}^{2+} / \mathrm{Mg}^{2+}$ oranı 1'den büyük, örneklerin \%78'inde ise oran 2'den büyüktür (Şekil 10). Buna göre yeraltısuları sisteminde silikat ayrışması oldukça baskın bir hidrojeokimyasal süreçlerden birisidir.

Şekil 11'de verilmiş olan $\mathrm{Ca}^{2+}+\mathrm{Mg}^{2+} / \mathrm{HCO}_{3}{ }^{-}+\mathrm{CO}_{3}{ }^{-2}$ diyagramında da su örneklerinin büyük kısmı 1:1 çizgisinin üzerine düşmektedir.

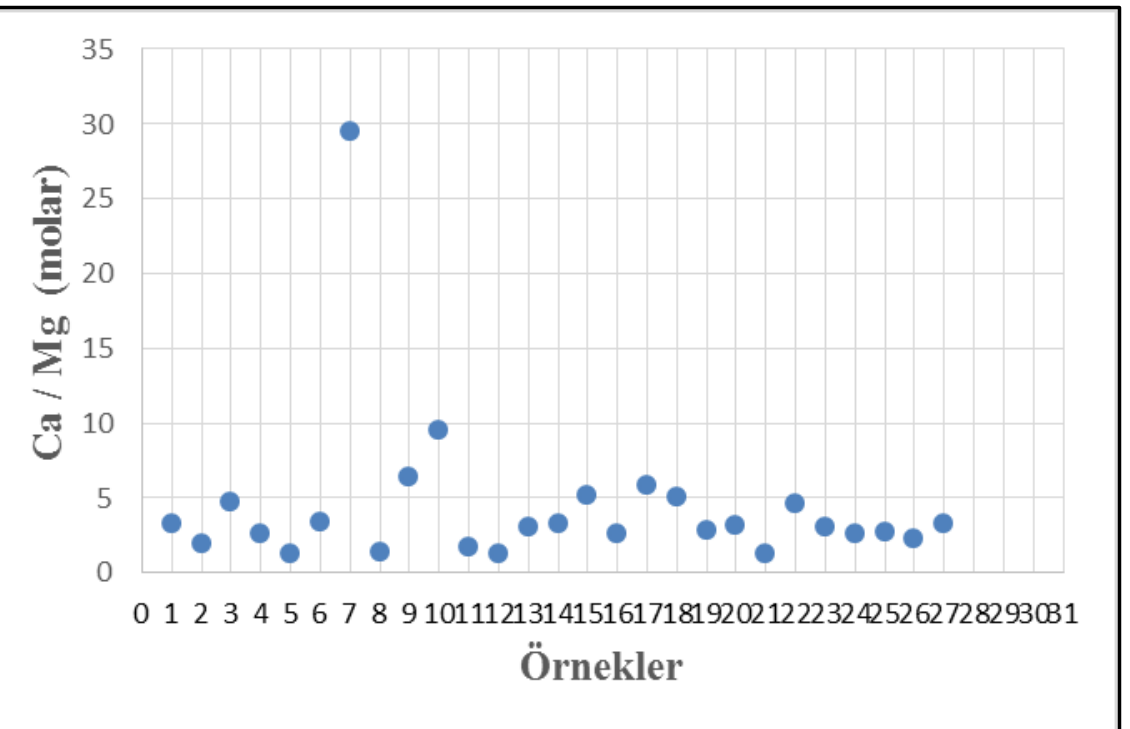

Şekil 10. Yeraltısularının molar $\mathrm{Ca}^{2+} / \mathrm{Mg}^{2+}$ oranı dağılım diyagramı 
Afyonkarahisar Şuhut Ovası Yeraltısularının Hidrojeokimyasal İncelemesi

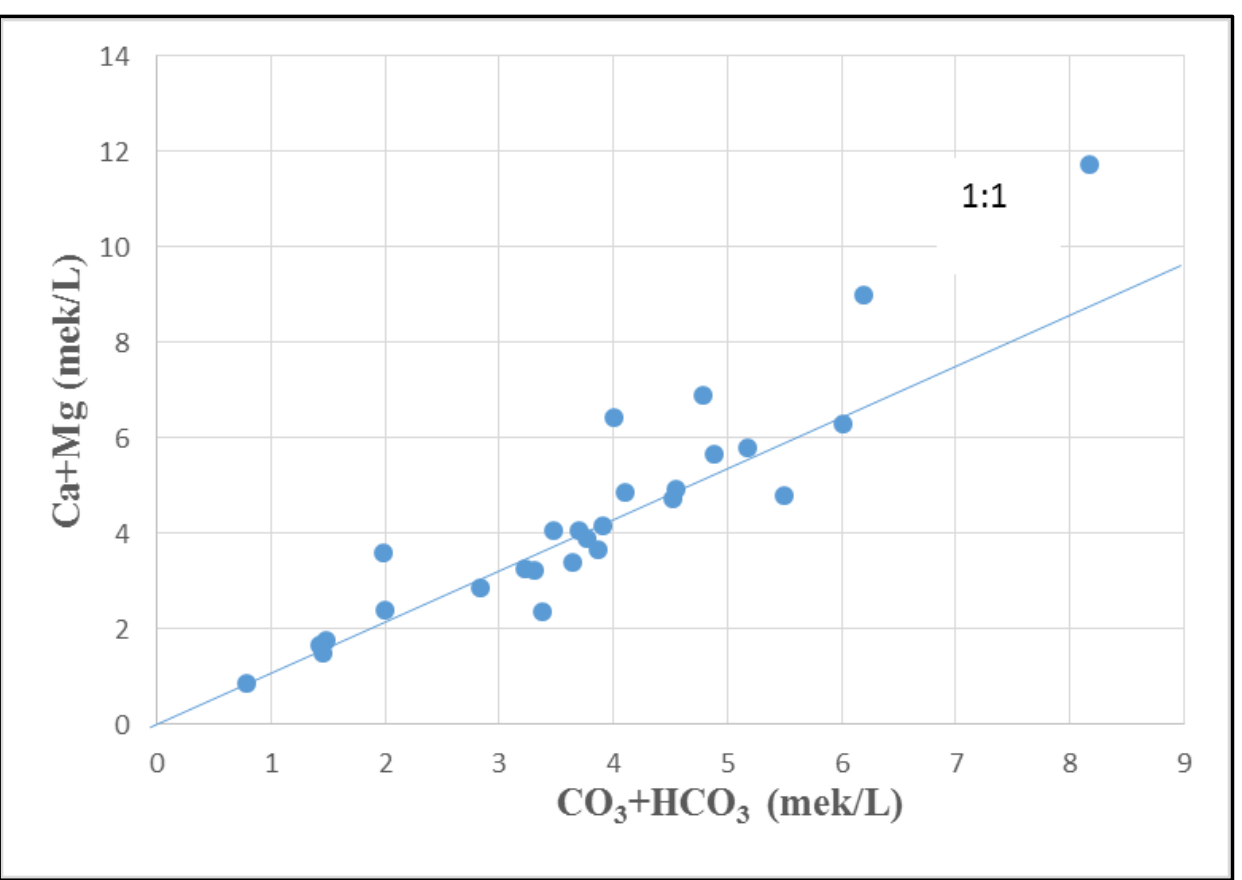

Şekil 11. Yeraltısularının $\mathrm{Ca}^{2+}+\mathrm{Mg}^{2+}$ ve $\mathrm{HCO}_{3}{ }^{-}+\mathrm{CO}_{3}{ }^{-}$diyagramı

Diyagrama göre 1:1 çizgisi üzerinde kalan bölgede yer alan örnekler $\mathrm{HCO}_{3}{ }^{-}$in alkali toprak metalleri ve karbonat litolojisi tarafından kontrol edildiğini gösterirken, 1:1 çizgisinin altındaki noktalar silikat ayrışması olabilecek diğer kaynağın etkisini göstermektedir. Buna göre çaıışma alanındaki örneklerdeki kalsiyum ve magnezyum iyonlarının karbonat olmayan farklı kaynaklardan su kimyasına karıştığını göstermektedir.

Yeraltısularının majör iyon kimyasını kontrol eden hidrojeokimyasal süreçlerden birisi de silikat ayrışmasıdır.
Sularda $\mathrm{Na}^{+}+\mathrm{K}^{+}$iyonlarına karşı toplam katyonlar (TK) arasındaki ilişki ile $\mathrm{Ca}^{2+}+\mathrm{Mg}^{2+}$ iyonlarına karşı toplam katyonlar arasındaki ilişki incelenerek silikat ayrışmasının varlığı anlaşılabilmektedir. Şekil 12'de verilen $\mathrm{Ca}^{2+}+\mathrm{Mg}^{2+}$ ve TK diyagramı incelendiğinde su örneklerinin çoğunun $\mathrm{Ca}+\mathrm{Mg}$ : 0.5 TK çizgisi ile 1:1 çizgisi arasında kaldığı görülmektedir. Şekil 13 'de verilen $\mathrm{Na}^{+}+\mathrm{K}^{+}$ ve TK diyagramında ise yine tüm su örnekleri $\mathrm{Na}+\mathrm{K}: 0.5$ TK çizgisinin altında kalmaktadır.

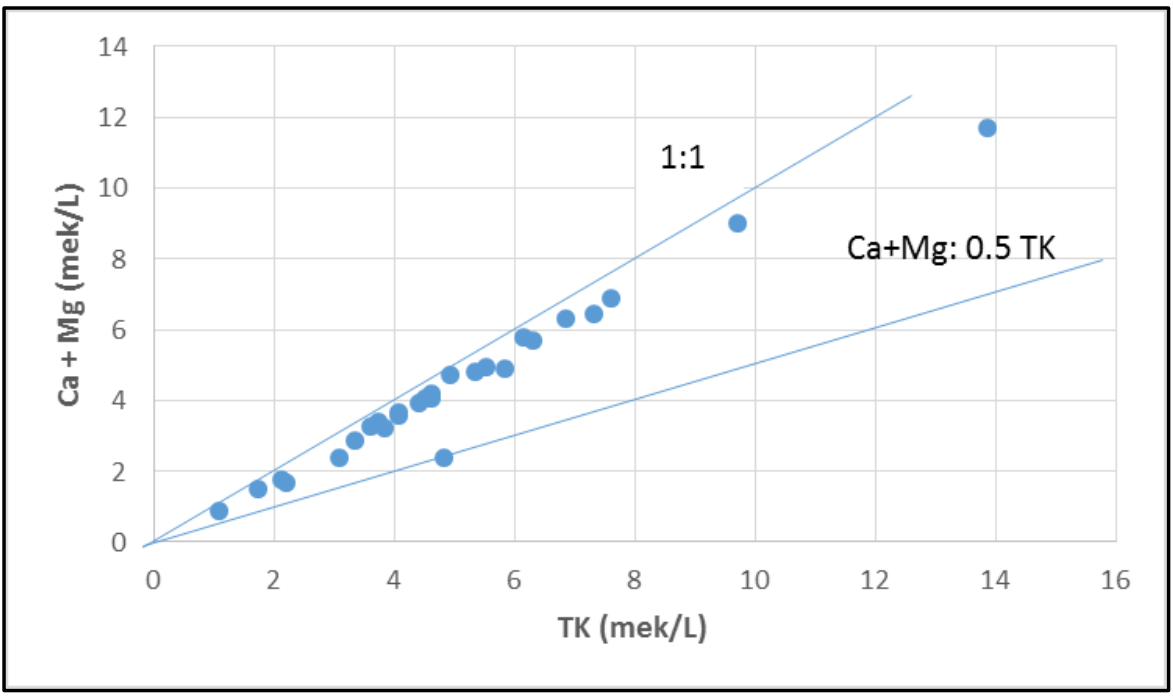

Şekil 12. Yeraltısularının $\mathrm{Ca}^{2+}+\mathrm{Mg}^{2+}$ ve $\mathrm{TK}$ diyagramı 
Afyonkarahisar Şuhut Ovası Yeraltısularının Hidrojeokimyasal İncelemesi

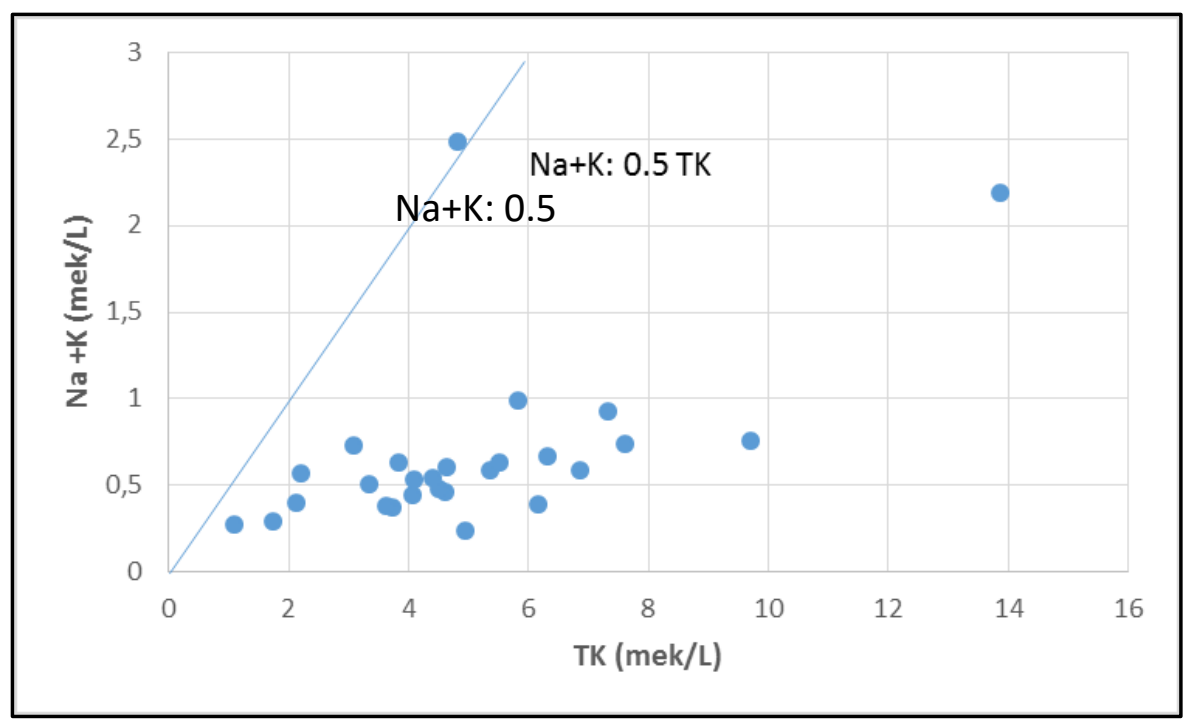

Şekil 13. Yeraltısularının $\mathrm{Na}^{+}+\mathrm{K}^{+}$ve $\mathrm{TK}$ diyagramı

Buna göre akifer ortamda karbonat ayrışmasının yanı sıra silikat ayrışması da gerçekleşmekte olup özellikle yeraltısularındaki $\mathrm{Na}$ ve $\mathrm{K}$ iyonlarının varlığı silikat ayrışmasının bir sonucu olarak gelişmektedir. Aynı zamanda, yeraltısularında $\mathrm{Na}^{+}$ve $\mathrm{K}^{+}$iyonlarının diğer bir kaynağı sodyum feldspat (albit) ve potasyum feldspatlar (ortoklaz ve mikroklin) olabilir (Sarin ve ark., 1989; Bozdağ, 2016).

Aynı zamanda incelenen yeraltısularında $\mathrm{Na}^{+}$ve $\mathrm{K}^{+}$iyonları arttıkça $\mathrm{Cl}^{-}$ve $\mathrm{SO}_{4}{ }^{2-}$ iyonlarında artış gözlenmektedir.
Bu da alüvyon ortamda toprak tuzlarının çözünmesi sonucu oluşan iyon zenginleşmesini desteklemektedir (Sarin ve ark., 1989). Su örneklerinin tamamında $\mathrm{Na}^{+} / \mathrm{Cl}^{-}$ molar oranı 1'den büyüktür (Şekil 14). Bu durumda, $\mathrm{Na}^{+}$ 'nın tuzların çözünmesinden ziyade silikat ayrışmasından (Na-plajiyoklaz veya ortoklaz) ve/veya iyon değişimi yoluyla kaynaklandığını göstermektedir (Kumar ve ark., 2009).

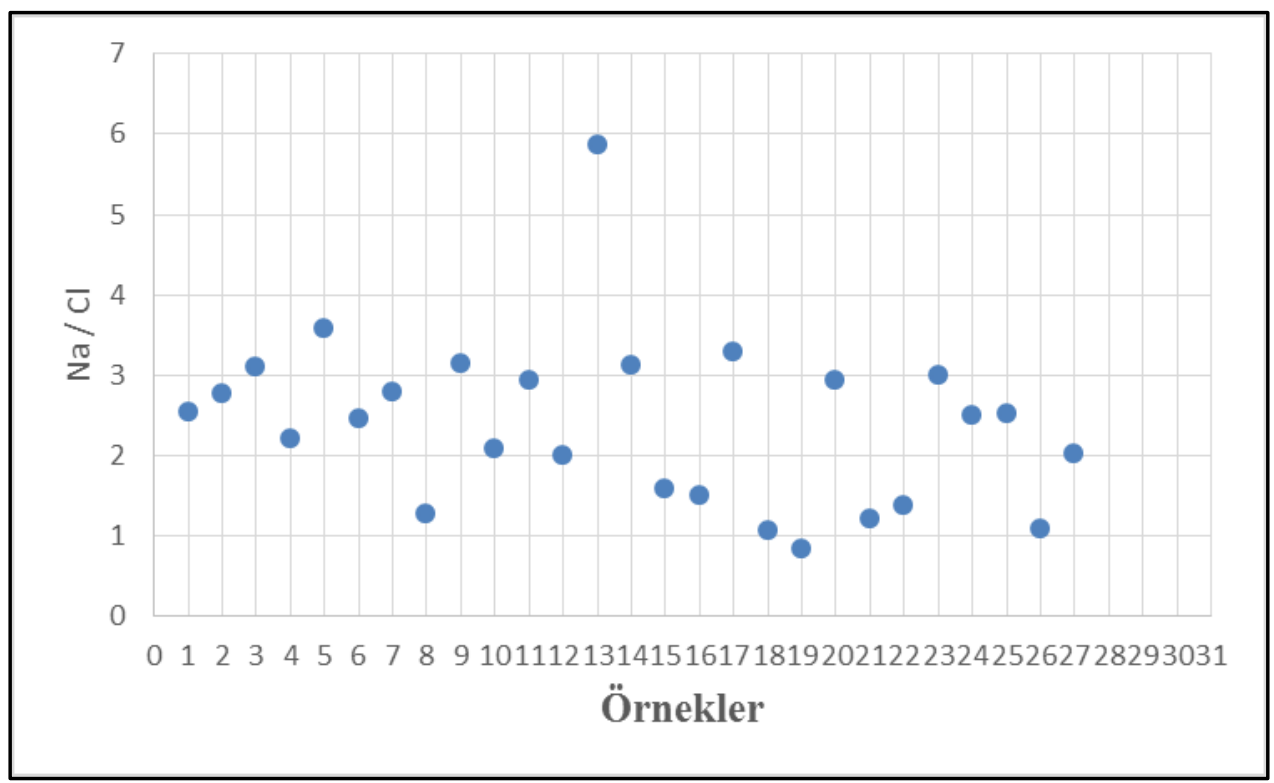

Şekil 14. Yeraltısularının molar $\mathrm{Na} / \mathrm{Cl}$ oranı dağılım diyagramı 
Aşağıda verilmiş olan eşitliklerde iyonların mek/L cinsinden değerleri kullanılarak hesaplanan Kloro-Alkalin İndisleri (KAi) I ve II değerleri, yeraltısuyundaki iyon değişim sürecinin oluşumunu belirlemek için kullanılmaktadir.

$$
\begin{gathered}
\mathrm{KAI}-1=[\mathrm{Cl}-(\mathrm{Na}+\mathrm{K})] / \mathrm{Cl} \\
\mathrm{KAI}-2=[\mathrm{Cl}-(\mathrm{Na}+\mathrm{K})] /\left(\mathrm{SO}_{4}+\mathrm{HCO}_{3}+\mathrm{NO}_{3}\right)
\end{gathered}
$$

Akifer ortamda, yeraltısuyunda bulunan kalsiyum ve magnezyum $\left(\mathrm{Ca}^{2+}, \mathrm{Mg}^{2+}\right)$ iyonları ile kayaçlardaki sodyum ve potasyum $\left(\mathrm{Na}^{+}, \mathrm{K}^{+}\right)$iyonları arasında değişim varsa, KAl değerleri negatiftir ve iyon değişimi söz konusudur. Eğer, yeraltısuyunda bulunan sodyum ve potasyum iyonları ile kayaçlardaki Ca ve Mg iyonları arasında bir değişim varsa, her iki indis de pozitiftir ve ters iyon değişimini gösterir (Schoeller 1965; Kumar ve ark., 2009; Aghazadeh ve Mogaddam, 2011). Çalışma alanındaki yeraltısularının tamamı için hesaplanan KAI değerleri negatiftir. Bu sonuç, yeraltısularının hidrojeokimyasal gelişiminde, bölgedeki jeojenik oluşum ve litolojik özelliklere bağlı olarak kalsiyum ve magnezyum iyonları ile sodyum ve potasyum iyonları arasında iyon değişiminin meydana geldiğini doğrulamaktadır. Bu durumda yeraltısuyu sisteminde $\mathrm{Na}^{+}$iyonlarının artışında iyon değişimi reaksiyonlarının rol oynadığı ve iyon değişiminin bölgedeki yeraltısuyu kimyasının kontrol eden ana süreçlerden biri olduğu söylenebilir.

\section{SONUÇLAR}

Şuhut Ovası Akarçay havzası içerisinde yer almakta olup bölge ülkemizin önemli tarım alanlarından birisidir. Şuhut havzası içerisinde kullanımda olan yüzey suları bulunmasına rağmen gerek kalite gerekse miktarlarındaki yetersizlikler sebebiyle önemli miktarlarda yeraltısuyu kullanımı da gerçekleşmektedir. Özellikle bölge halkı tarafından içme ve sulama suyu olarak kullanılan yeraltısularının hidrojeokimyasal özelliklerinin ortaya konulması amacıyla yapılan çalışmada 27 farklı su örneğinin fizikokimyasal özellikleri belirlenmiştir. Ayrıca, kayaçsu etkileşimi ile su kimyasını doğrudan etkileyen jeolojik birimler ayrıntılı olarak incelenmiştir. Çalışma alanında akifer özelliği gösteren başlıca birimler alüvyon ve yamaç molozlarıdır. Karbonatlı kayaçlar karstik akifer özelliğinde, tüf, tüfit ve aglomera gibi volkanikler, kumtaşı, konglomera ardalanmaları yarı geçirimli birimlerdir. ÇaIışma alanındaki metamorfikler, filiş karakterindeki birimler ve ofiyolitik birimler ise geçirimsiz birimlerdir. Havzada yeraltısuyu genel olarak alüvyon birimden ve yer yer alüvyonun alt sevilerinde bulunan kireçtaşı birimlerinde alınmaktadır. Su örneklerinin fizikokimyasal ve majör iyon konsantrasyonları değerlendirilmiş ve kuyulardan alınan örneklerin hidrojeokimyasal fasiyesini belirle- mek için Piper Diyagramı kullanılmıştır. Piper Diyagramı'ndan elde edilen sonuçlara göre, çalışma alanında $\mathrm{Ca}-\mathrm{Mg}-\mathrm{HCO}_{3}$ ve $\mathrm{Ca}-\mathrm{HCO}_{3}$ baskın su tipleri olarak belirlenmiştir. Suların fizikokimyasal analiz sonuçları kullanılarak hazırlanan iyon dağılım haritalarına göre ovanın orta kesimlerinde iyon miktarlarının artış gösterdiği belirlenmiştir.

Hazırlanan Gibbs Diyagramlarına göre, su kimyasının oluşumunda etkili olan ana süreç kaya su etkileşimidir. Bununla birlikte yeraltısuyu örneklerinin hidrokimyasal yapısının gelişiminde karbonat ayrışması, silikat ayrışması ve iyon değişimi de başlıca hidrojeokimyasal süreçlerdir. Bölgede yaygın olarak yüzeyleyen karbonatı kayaçların, volkanik kayaçların ve bu birimlerden türemiş alüvyon biriminin içerdiği mineraller su kimyasına etki etmektedir. Volkanik birimlerde yoğun olarak $\mathrm{Na}-\mathrm{Ca}$ feldspat ve koyu renkli silikat mineralleri (biyotit, amfibol, piroksen) egemendir. Genel olarak Ca iyonlarının artışı karbonatlı minerallerin yanı sıra Ca feldspatlar ile ilişkilidir. Mg iyonlarının artışı ise daha çok biyotit, amfibol, piroksen gibi silikat minerallerinin ayrışması sonucunda gerçekleşmektedir. $\mathrm{HCO}_{3}$ iyonu da bölgede yer yer çökelmiş olan kireçtaşı, killi kireçtaşı birimleri ile birlikte feldspat minerallerinin ayrışması sonucunda açığa çıkan kalsit mineralleri ile ilişkili kaya-su etkileşimi sonucunda artı̧̧ göstermektedir. Yeraltısuyu örneklerinde yüksek miktarlarda ölçülmüş olan $\mathrm{NO}_{3}$ suların kullanımını kısıtlayan bir kirlilik göstergesidir. Özellikle Hallaç, Mahmut ve Bademli civarındaki sondaj kuyularından alınan su örneklerinin sınır değerlerin (>50 mg/L) üzerinde nitrat içerdiği belirlenmiştir. Bu bölgedeki yeraltısularının içme suyu olarak kullanılması uygun değildir.

Sonuç olarak yeraltısuyu ile ilgili problemlerin çözümünde yeraltısuyunun miktar ve kalitesini etkilemesi muhtemel kullanım miktarlarının, iklim değişikliği ile bağlantılı olarak hidrolojik süreçlerin, jeojenik ve antropojenik kirletici etkilerinin tespit edilmesi son derece önemlidir. Ayrıca, mevcut ve gelecekte olması beklenen bu gibi baskı unsurları karşısında yeraltısuyu potansiyeli ve kalite durumundaki değişimlerin zamansal ve konumsal olarak belirlenmesi gerekmektedir. Bunu gerçekleştirirken sadece sistemin kendisi değil sistemin etkileştiği sistemler de dikkate alınmalıdır. Bu bağlamda Şuhut Ovası yeraltısularının hidrojeokimyasal incelenmesinin amaçlandığı bu çalışmada elde edilen sonuçlar temelinde bölgede özellikle içme ve sulama suyu ihtiyacını karşılamakta olan yeraltısularının miktar ve kalite olarak sürdürülebilirliğinin sağlanması için kapsamlı çalışmaların yapılması önerilmektedir. 


\section{KAYNAKLAR}

Aghazadeh, N., Mogaddam, A.A. (2011). Investigation of hydrochemical characteristics of groundwater in the Harzandat aquifer, Northwest of Iran. Environmental Monitoring and Assessment, 176: 183-195.

ASTM D6517-00 (2000). Standard Guide for Field Preservation of Ground-Water Samples, ASTM International, West Conshohocken, PA, www.astm.org, DOI: 10.1520/D651700

ASTM D5903-96 (2017). e1, Standard Guide for Planning and Preparing for a Groundwater Sampling Event, ASTM International, West Conshohocken, PA, www.astm.org, DOI: 10.1520/D5903-96R17E01

ASTM D4448-01 (2019a). Standard Guide for Sampling Ground-Water Monitoring Wells, ASTM International, West Conshohocken, PA, www.astm.org

ASTM D6089-19 (2019b), Standard Guide for Documenting a Groundwater Sampling Event, ASTM International, West Conshohocken, PA, www.astm.org, DOI: 10.1520/D608919

Bozdağ, A. (2016). Assessment of the hydrogeochemical characteristics of groundwater in two aquifer systems in Çumra Plain, Central Anatolia. Environmental Earth Sciences, 75(8): 1-15.

Gibbs, R.J. (1970). Mechanisms controlling world water chemistry. Science, 17: 1088-1090.

Kazi T.G., Arain M.B., Jamali M.K., Jalbani N., Afridi H.I., Sarfraz R.A., Baig J.A., Shah A.Q. (2009). Assessment of water quality of polluted lake using multivariate statistical techniques: a case study. Ecotoxicology and Environmental Safety, 72:301-309.

Kumar, M., Kumari, K., Singh, U.K., Ramanathan, A.L. (2009). Hydrogeochemical processes in the groundwater environment of Muktsar, Punjab:conventional graphical and multivariate statistical approach. Environmental Geology, 57: 873- 884

Lakshmanan, E., Kannan, R., Kumar, M.S. (2003). Major ion chemistry and identification of hydrogeochemical processes of ground water in a part of Kancheepuram district, Tamil Nadu, India. Environmental Geosciences, 10(4): 157166.

Laxmankumar D., Satyanarayana E., Dhakate R. Saxena P.R. (2019). Hydrogeochemical characteristics with respect to fluoride contamination in groundwater of Maheshwarm mandal, RR district, Telangana state, India. Groundwater for Sustainable Development, 8: 474-483.

Li F., Zhu J., Deng X., Zhao Y., Li S. (2018). Assessment and uncertainty analysis of groundwater risk. Environmental Research, 160: 140-151.

Mülga Orman ve Su İşleri Bakanlığı, (2013). Akarçay Havzası Hidrojeolojik Etüt Raporu, Orman ve Su İşleri Bakanlığı, Devlet Su İşleri 18. Bölge Müdürlüğü, Isparta.

Nadiri A.A., Moghaddam A.A., Tsai F.T., Fijani E. (2013). Hydrogeochemical analysis for Tasuj plain aquifer, Iran. Journal of Earth System Scince, 122(4): 1091-1105.
Özgül, B., (2000). Şuhut Ovasının Hidrojeoloji İncelemesi. Süleyman Demirel Üniversitesi, Fen Bilimleri Enstitüsü, Yüksek Lisans Tezi, Isparta.

Piper. A.M. (1944). A graphic procedure in the geochemical interpretation of water analyses. Transactions, American Geophysical Union, 25: 914-923.

Rao, N. S., Chaudhary, M. (2019). Hydrogeochemical processes regulating the spatial distribution of groundwater contamination, using pollution index of groundwater (PIG) and hierarchical cluster analysis (HCA): a case study. Groundwater for Sustainable Development, 9: 100238.

Redwan, M., Moneim, A.A.A., Amra, M.A. (2016). Effect of water-rock interaction processes on the hydrogeochemistry of groundwater west of Sohag area, Egypt. Arabian Journal of Geosciences, 9(2): 111; DOI 10.1007/s12517015-2042-x

Sargın, A.H. (2010). Groundwaters. General Directorate of State Hydraulic Works (SHW) Geotechnical Services and Groundwater Department. 200 p. Ankara-Turkey.

Sargın, A.H. (2020). Sürdürülebilir Yeraltısuları Yönetimi için Yeraltısuyu Kütlelerinin Etkileşen Sistemler Yaklaşımıyla İrdelenmesi: Örnek Bir Uygulama. Hacettepe Üniversitesi, Fen Bilimleri Enst., Jeoloji (Hidrojeoloji) Mühendisliği Anabilim Dalı, Doktora Tezi, 209 s. Ankara-Turkey.

Sarin, M.M., Krishnaswamy, S., Dilli, K., Somayajulu, B.L.K., Moore, W.S. (1989). Major ion chemistry of the GangaBrahmaputra river system: Weathering process and fluxes to the Bay of Bengal. Geochimica et Cosmochimica Acta, 53: 997-1009.

Schoeller, H. (1965). Hydrodynamique lans lekarts (ecoulemented emmagusinement). Actes Colloques Doubronik, I,AlHS et UNESCO, 3-20.

Şener, Ş., Şener, E., Nas, B., Karagüzel, R. (2010). Combining AHP with GIS for landfill site selection: a case study in the Lake Beyşehir catchment area (Konya, Turkey). Waste management, 30(11): 2037-2046.

Şener, E., Şener, Ş. (2015). Evaluation of groundwater vulnerability to pollution using fuzzy analytic hierarchy process method. Environmental Earth Sciences, 73(12): 84058424.

TS (1997a), TS 5090. EN 25667-2/Nisan, Su Kalitesi - Numune Alma Bölüm 2: Numune Alma Teknikleri - Kılavuzu.

TS (1997b), TS 5106 ISO 5667-3/Nisan, Su Kalitesi - Numune Alma Bölüm 3: Numunelerin Muhafaza ve Taşınma Kuralları.

Varol, S., Davraz, A. (2014). Assessment of geochemistry and hydrogeochemical processes in groundwater of the Tefenni plain (Burdur/Turkey). Environmental Earth Sciences, 71(11): 4657-4673.

Yetiş, A.D. (2013). Determination of Ceylanpınar Plain Groundwater Quality and Pollution Potential. Çukurova University, Institute of Science, Department of Environmental Sciences, PhD thesis. Adana-Turkey. (Supported by Research Projects Unit. Project No: MMF2012D5) 